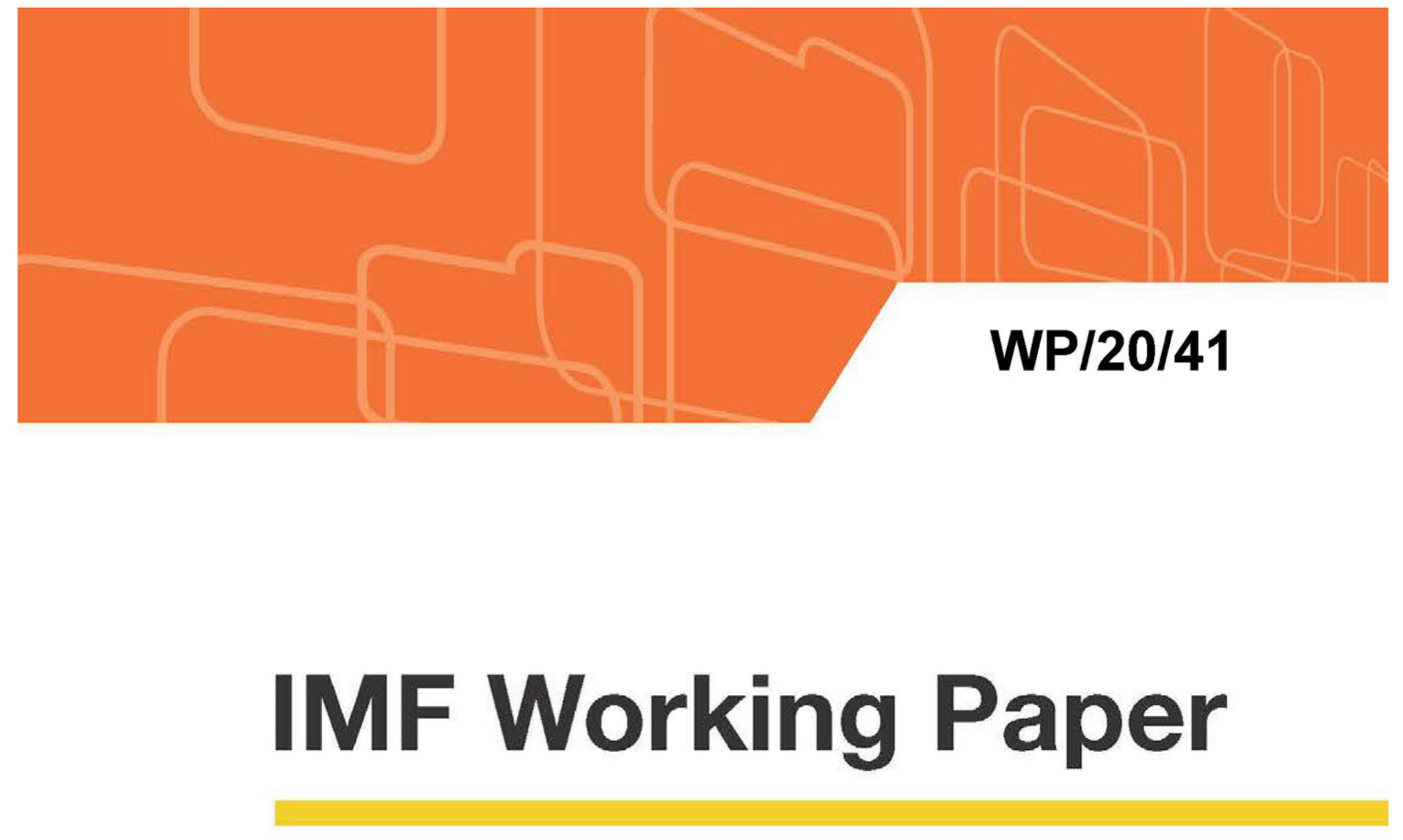

\title{
The Impact of Conflict and Political Instability on Banking Crises in Developing Countries
}

By Ali Compaoré, Montfort Mlachila, Rasmané Ouedraogo, and Sandrine Sourouema

IMF Working Papers describe research in progress by the authors and are published to elicit comments and to encourage debate. The views expressed in IMF Working Papers are those of the authors and do not necessarily represent the views of the IMF, its Executive Board, or IMF management. 


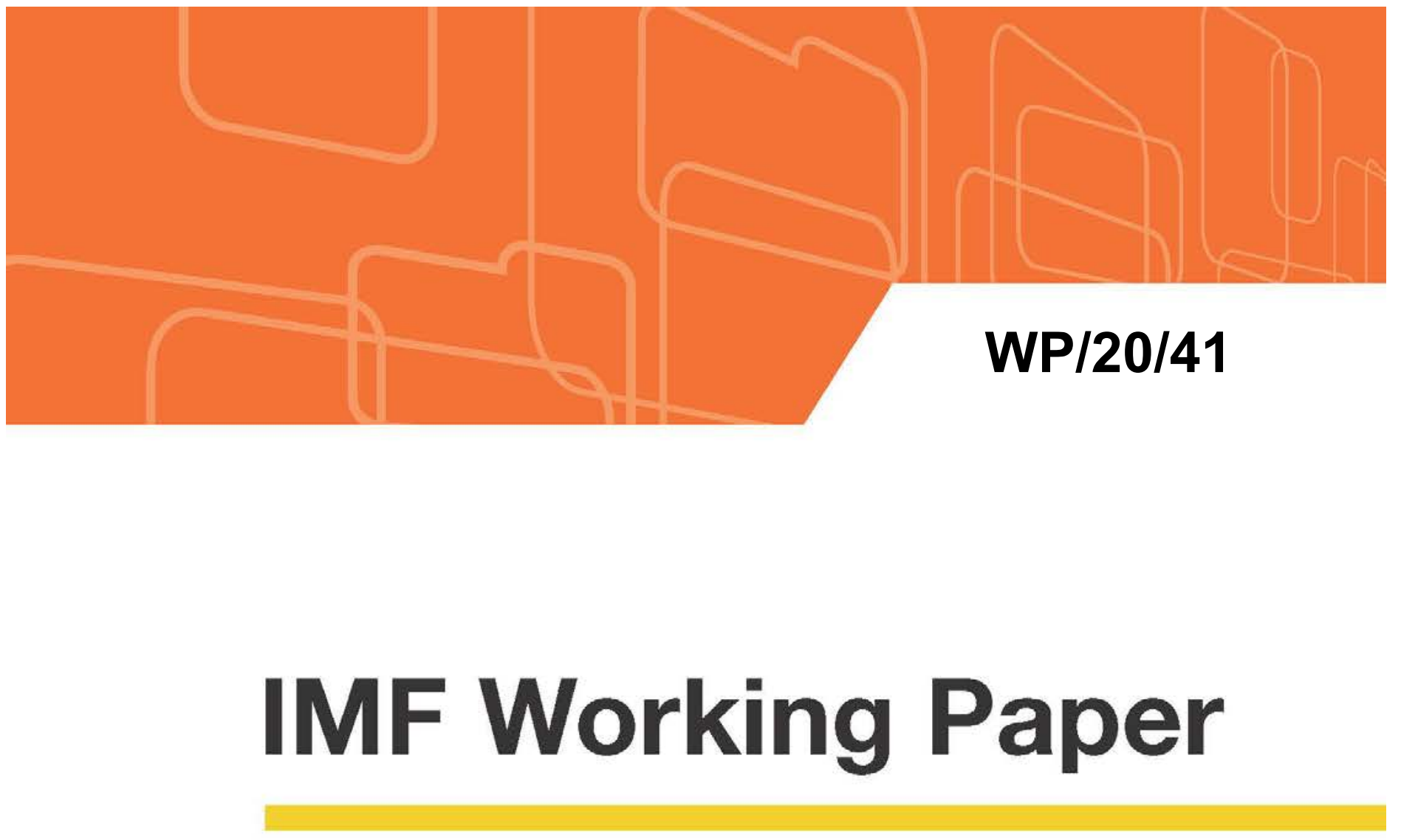

\section{The Impact of Conflict and Political Instability on Banking Crises in Developing Countries}

By Ali Compaoré, Montfort Mlachila, Rasmané Ouedraogo, and Sandrine Sourouema

IMF Working Papers describe research in progress by the authors and are published to elicit comments and to encourage debate. The views expressed in IMF Working Papers are those of the authors and do not necessarily represent the views of the IMF, its Executive Board, or IMF management.

$$
\text { I N T E R N A T I O N A L M O N E T A R Y F U N D }
$$




\title{
IMF Working Paper
}

\author{
African Department
}

\section{The Impact of Conflict and Political Instability on Banking Crises in Developing Countries}

\section{Prepared by Ali Compaoré, Montfort Mlachila, Rasmané Ouedraogo, and Sandrine Sourouema ${ }^{1}$}

February 2020

\section{IMF Working Papers describe research in progress by the authors and are published to elicit comments and to encourage debate. The views expressed in IMF Working Papers are those of the authors and do not necessarily represent the views of the IMF, its Executive Board, or IMF management.}

\begin{abstract}
While there is an extensive literature examining the economic impact of conflict and political instability, surprisingly there have been few studies on their impact on the probability of banking crises. This paper therefore investigates whether rising conflict and political instability globally over the past several decades led to increased occurrence of banking crises in developing countries. The paper provides strong evidence that conflicts and political instability are indeed associated with higher probability of systemic banking crises. Unsurprisingly, the duration of a conflict is positively associated with rising probability of a banking crisis. Interestingly, the paper also finds that conflicts and political instability in one country can have negative spillover effects on neighboring countries' banking systems. The paper provides evidence that the primary channel of transmission is the occurrence of fiscal crises following a conflict or political instability.

JEL Classification Numbers: G01, H56

Keywords: conflict, political instability, banking crises, fiscal crises

Author's E-Mail Address: ali.compaore@etu.uca.fr, mmlachila@,imf.org, rouedraogo@imf.org, sandrinewsourouema@yahoo.fr
\end{abstract}

\footnotetext{
${ }^{1}$ We would like to thank, without implication, Sophia Chen, Ana Lucia Coronel, Eric Pondi Endengle, Jiaxiong Yao, and the participants at the African Department seminar series for useful comments and suggestions.
} 


\section{Table of Contents}

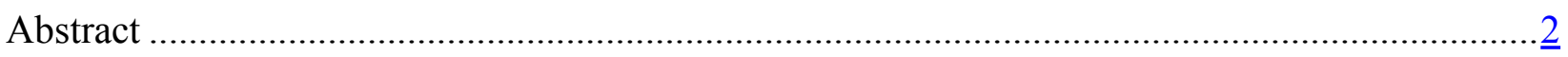

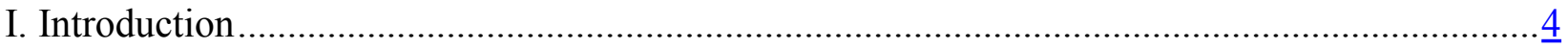

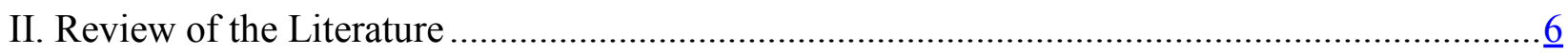

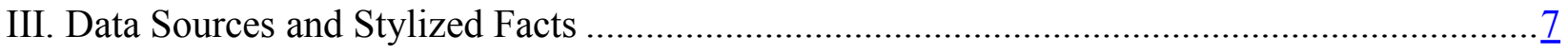

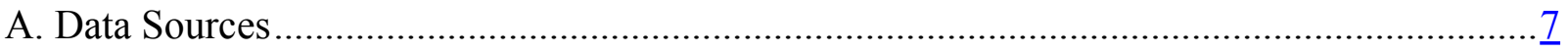

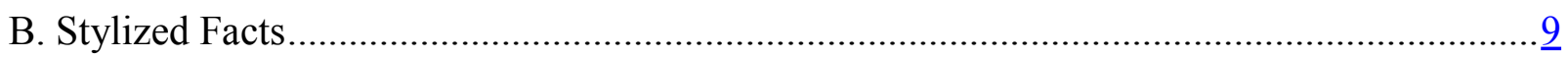

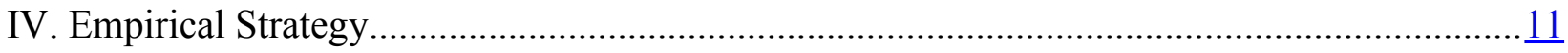

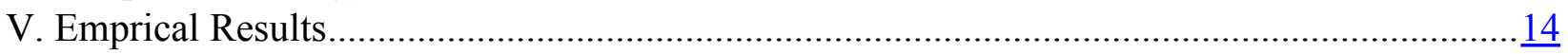

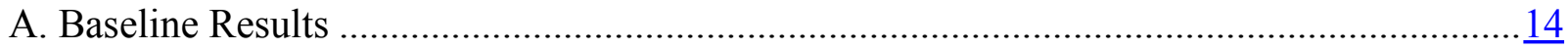

B. Do Conflicts and Political Instability in Neighboring Countries Matter? ………………......20

C. Duration of Conflict and Political Instability …………..................................................

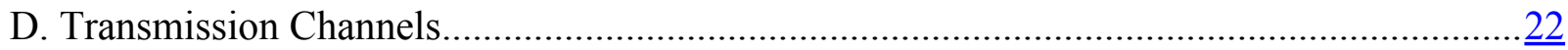

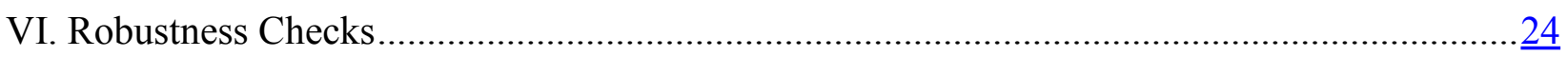

A. Use of Alternative Data Sources …………………….................................................

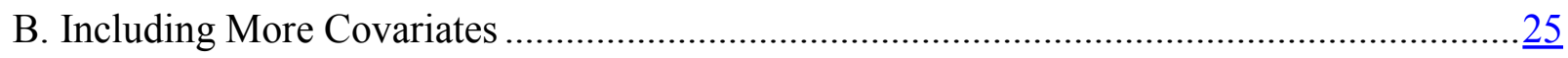

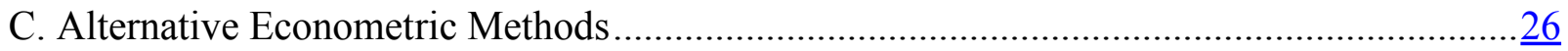

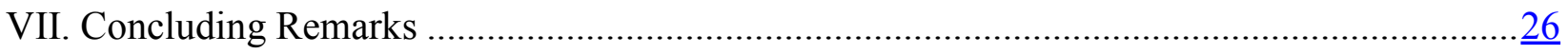

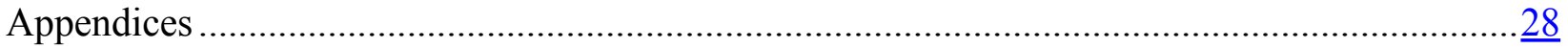

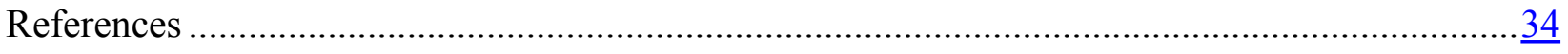




\section{INTRODUCTION}

There has been a marked proliferation of violence and conflicts across developing countries over the past two decades, especially in the wake of the Arab spring from 2011 (Figure 1). The nature of the violence is diverse and includes ethnic and religious conflicts, terrorism, post-electoral conflicts, civil wars, and, most importantly armed conflicts. ${ }^{2}$ Violence has undoubted deep socio-economic impact on affected countries and their neighbors. For instance, the World Bank (2017) estimates at more than 400,000 the death toll and US\$200-300 billion the loss in GDP in Syria since the conflict started in 2011.

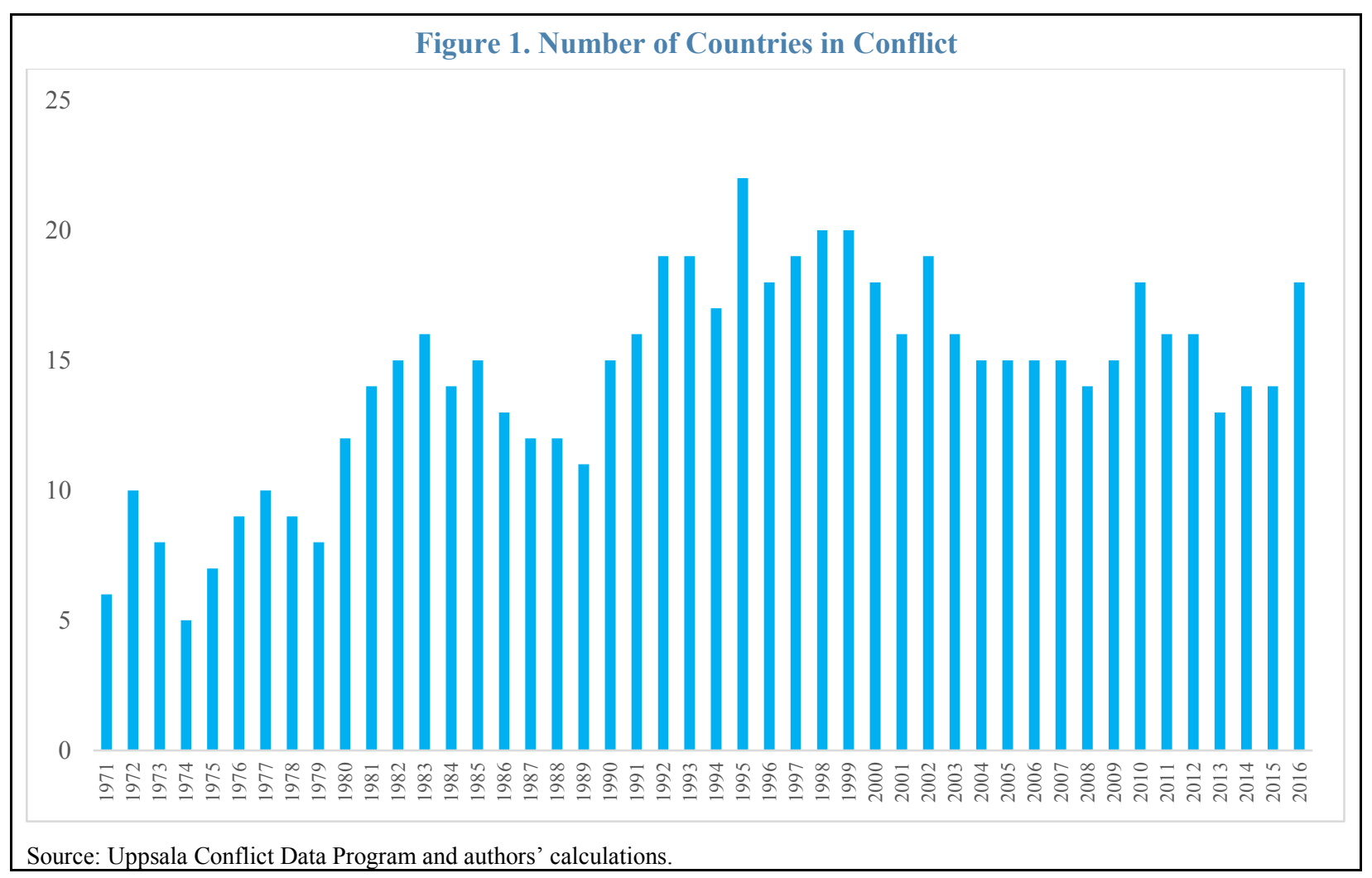

Conflicts and violence have severe negative consequences on the affected economies, which can spill over to their neighboring countries. In addition to the loss of lives, human displacement and the material destruction caused, conflicts can result in deep economic recession stemming from high inflation, worsened fiscal and financial positions, and lower institutional quality (Rother et al., 2016). In addition, internal instability entails a decline in investor and consumer confidence, and trade disruption (Rother et al., 2016). According to the IMF (2019), on average, in conflictaffected countries annual real GDP growth is 3 percentage points lower and the cumulative impact on per-capita GDP increases over time. Furthermore, internal conflicts have negative spillovers on neighboring countries, whose GDP growth typically declines by about 1 percentage point, on average.

In this paper, we explore the impact of conflicts on the probability of banking crises, a channel that has hitherto received little attention in the literature. The literature has largely focused on the

${ }^{2}$ See Human Rights Watch's World Report 2018

https://www.hrw.org/sites/default/files/world_report_download/201801world_report_web.pdf 
potential consequences of risks of instability on other socio-economic outcomes. It is well-documented that instability has adverse effects on countries' long-run economic performance (Alesina et al., 1996; Alesina and Perotti, 1996; Jong-A-Pin, 2009; Aisen and Veiga, 2013; Rother et al., 2016, Murdoch and Sandler, 2002), public investment (Alesina et al. 1996, IMF 2019), trade (Qureshi, 2013), tourism (Neumayer, 2004) and fiscal outcomes (IMF 2019). Surprisingly, to our knowledge, there is no empirical study on the potential impact of conflict on banking crises. Although IMF (2019) and Rother et al. (2016) allude to the fact that conflicts can lead to lower performance in the banking sector, they do not provide empirical evidence on whether conflicts and political instability can trigger actual systemic banking crises.

Conflicts and political instability can indeed be associated with a greater risk of systemic banking crisis. Conceptually, there are several channels through which conflicts can lead to banking crises. These include lower economic growth, higher non-performing bank loans, lower bank deposits and liquidity, and fiscal channels. Rother et al. (2016) emphasized that conflicts weaken the performance of the financial sector and deteriorate banks' ability to sustain financial intermediation and payment systems. A recent study by Huang (2019) found that political instability decreases banks' balances, liabilities and assets. Beim (2005) enumerated several cases of systemic banking crises that occurred in times of conflict and political instability. For instance, in 1995, during the civil war in Sierra Leone, 40 to 50 percent of banking system loans were non-performing (NPLs) and a license of one of the banks was suspended in 1994. Gobat and Kostial (2016) found that the Syrian conflict deeply affected the banking sector by causing deposit and assets runs, and raising NPLs from less than 5 to 35 percent of total loans over 2010-2013.

This paper fills the gap in the literature by rigorously studying the potential impact of conflict and political instability on systemic banking crisis in 92 developing countries over the period 1970-2016. First, it explores this by using various different measures of conflict and political instability on the probability of banking crises. Second, the paper analyzes spillovers of conflict and political instability from one country to another. Third, it examines whether the duration of conflict and political instability increases the probability of banking crises. Fourth, it explores the channel through which conflict and political instability affect the likelihood of banking crises.

The paper has three main results. First, it shows that conflicts and political instability are indeed associated with higher probability of systemic banking crises. Specifically, it finds that the odds of a banking crisis are 2.5 times greater when a country is affected by a conflict. Second, conflicts and political instability in neighboring countries do increase the likelihood of banking crises in a given country, although the spillover effects are less impactful than primary channels. Third, the duration of a conflict is positively associated with rising probability of a banking crisis. In terms of magnitude of the impact, the probability of experiencing a banking crisis is 25 percent when the conflict lasts 10 years, against 16.4 percent when it lasts two years.

The paper provides evidence that the likely channel of transmission is the occurrence of fiscal crises following a conflict or political instability. The findings are robust to the use of alternative conflict and political instability indicators from 10 different sources, alternative empirical strategy, and the inclusion of additional covariates. This paper contributes to the vast literature on the adverse effects of conflict and political instability. It is the first to provide a comprehensive empirical study about the impact of conflict and political instability on the likelihood of banking crises in developing countries. Previous studies have provided several claims on the specific 
cases of some countries (Beim, 2005; Rother et al., 2016), but they lacked strong empirical evidence on a large sample of countries to back up or substantiate the claims.

The rest of the paper is organized as follows. Section 2 briefly reviews the literature on the determinants of banking crises and the potential mechanisms through which conflicts can provoke banking crises. Section 3 describes the data and provides some stylized facts, and Section 4 discusses the empirical strategy. Section 5 presents the results from the empirical analysis. Section 6 undertakes an extensive battery of robustness texts. Section 7 provides some concluding remarks.

\section{REVIEW OF THE LITERATURE}

There is an increasing literature on the economic consequences of conflicts and political instability, with a particular emphasis on economic growth, income inequality and poverty (Collier, 1999; Murdoch and Sandler, 2004; Lai and Thyne, 2007; Polachek and Sevastianova, 2012; Mueller, 2013). For instance, Gates et al. (2012) showed that armed conflicts led to development gaps and compromised the progress in meeting the United Nation's Millennium Development Goals (MDGs) by undermining the efforts to reduce poverty, hunger and infant mortality, improve life expectancy as well as access to potable water. Ghobarah et al. (2003) also emphasized the adverse long-lasting effects of conflicts on development outcomes. Beyond the impact on the economy at the aggregate level, some papers looked at the change in the structure of economies affected by conflict. Depetris Chauvin and Rohner (2009) found that the manufacturing sector is the most affected in conflict affected countries, while natural resource sector appears to be over-exploited in times of conflict.

Another wave of the literature has focused on the fiscal implications of conflicts and political instability (IMF 2019; Gupta et al., 2004; Rother et al., 2016). Internal instability impedes on government revenue by disrupting economic activity, destroying the tax base, and lowering the efficiency of tax administration (IMF 2019). Barrett (2018) revealed that the conflict in Afghanistan led to a total revenue loss of about $\$ 3$ billion between 2005 and 2016, resulting mainly from a significant decline in revenue collection efficiency. Similarly, Rother et al. (2016) emphasized that central government revenue collapsed by about 60 percent following the outbreak of the conflict in Yemen in 2015. They also argued that the decline in both internal revenue collection and external financing combined with the increase in government spending have resulted in worsened fiscal positions in the Middle East and North African countries in conflict.

Focusing on sub-Saharan Africa, IMF (2019) found that conflicts entail, on average, a loss of tax revenue by about 2 percent of GDP, affect the composition of government expenditures, and worsen the fiscal balance. Using an intertemporal model, Pasten and Cover (2010) highlighted that political instability results in fiscal deficits, and this happens because political instability gives the government an incentive to implement a myopic fiscal policy in order to increase its chances of remaining in office.

However, there is a paucity of studies about the effects of conflicts and political instability on the banking sector. Rother et al. (2016) argued that conflicts weaken the performance of the financial sector and deteriorate banks' ability to sustain financial intermediation and payment systems, but they did not provide any empirical findings. Recently, IMF (2019) found that conflicts result in lower credit to the private sector. Huang (2019) investigated the impact of political instability on 
banking sector development on a panel of 49 countries over 1960-2004. The paper found that political instability deteriorates banks' balance sheets, generates inefficiencies in the operational management of banks and affects asset and liability allocation. Hasanov and Bhattacharya (2019) explored the effect of political factors on the likelihood of a banking crisis using a sample of OECD countries. They shed light that countries with higher government stability tend to have lower likelihood of a banking crisis. Gobat and Kostial (2016) asserted that the Syrian conflict deeply affected the banking sector by causing deposit and assets runs, and rising NPLs from less than 5 to 35 percent over 2010-2013.

As described above, several papers have found that conflict and political instability often lead to a deterioration of government fiscal positions. We draw on the literature about the transmission of crises from the government fiscal positions to the banking sector (Von Hagen and Ho, 2007; Reinhart and Kaminsky, 1999; Dornbusch et al., 1995). According to this literature, banking crises happen often after a fiscal crisis. In fact, worsened fiscal positions can trigger a banking crisis due to the balance-sheet linkages and banks' direct portfolio exposures (Caprio and Honohan, 2008; Caruana and Avdjiev, 2012) and the potential impact of debt defaults on the economy (lower growth, high non-performing loans, etc.) (Gertler and Kiyotaki, 2010). Budgetary pressures erode the government's ability to pay its bills, which can cause an accumulation of arrears to commercial enterprises and banks and increasing banks' non-performing loans. Moreover, sovereign debt is often used by banks as collateral to secure wholesale funding. Higher sovereign risk can reduce the eligibility of collateral, and hence banks' funding capacity and increase bank vulnerabilities (Popov and Van Horen, 2013).

\section{Data Sources ANd STYLized Facts}

\section{A. Data Sources}

The dataset consists of yearly data for 92 emerging and developing countries during the period 1970-2016. The selection of the sample is exclusively based on data availability.

We first focus on the dependent variables. The data on systemic banking crisis are from Laeven and Valencia (2018). The authors define a banking crisis as an event that meets two conditions: (i) significant signs of financial distress in the banking system (as indicated by significant bank runs, losses in the banking system, and/or bank liquidations); (ii) significant banking policy intervention measures in response to significant losses in the banking system. On the second condition, Laeven and Valencia (2018) consider policy interventions in the banking sector to be significant if at least three out of the following six measures have been used: (a) deposit freezes and/or bank holidays; (b) significant bank nationalizations; (c) bank restructuring fiscal costs (at least 3 percent of GDP); (d) extensive liquidity support (at least 5 percent of deposits and liabilities to nonresidents); (e) significant guarantees put in place; and (f) significant asset purchases (at least 5 percent of GDP). Our sample covers 191 episodes of banking crises.

Regarding the data on conflict and political instability, we collected a range of indicators from several sources, covering most of those that have been used in the literature. First, we extract the data on civil war from the Uppsala Conflict Data Program (UCDP) provided by the Department of Peace and Conflict Research, Uppsala University. In this database, internal armed conflicts are defined as a contested incompatibility concerning government and/or territory with the use of armed force between two parties, of which at least one is the government of a state. The database provides an intensity-scaled measure of internal armed conflicts, which takes the value of 1 if the internal conflict's related death toll in a given year is 25-999, 2 if it is 1000 or more, and 
0 otherwise. Based on this definition, we also construct an additional binary variable equal to 1 if a civil conflict happens in the country and 0 otherwise as in Miguel et al. (2014) and Holder and Raschky (2014).

Second, we extract some indicators of political instability from Banks and Wilson (2019)'s Cross-National Time-Series Data Archive. We use 6 indicators from this database that have been widely used in the literature as proxies of political instability (see Alesina et al. 1996; Aisen and Veiga, 2013; Neumayer 2004):

(i) Government cabinet changes. Represents the number of time in a year that a new premier minister is named and/or 50 percent of the cabinet posts are assumed by new ministers;

(ii) Changes in effective executive. Measures the number of times in a year that effective control of executive power changes hands. Such a change requires that the new executive be independent from its predecessor. This variable addresses one of drawbacks of the indicator related to major government changes as some cabinet changes may not entail change in executive power;

(iii) Anti-government demonstrations. Captures any peaceful public gathering of at least 100 people for the primary purpose of displaying or voicing their opposition to government policies or authority, excluding demonstrations of a distinctly anti-foreign nature;

(iv) Major government crises. Denotes any rapidly developing situation that threatens to bring the downfall of the present regime-excluding situations of revolt aimed at such overthrow;

(v) General strikes. Measures any strike of 1,000 or more industrial or service workers that involves more than one employer and that is aimed at national government policies or authority; and

(vi) Political assassinations. Represents any politically motivated murder or attempted murder of a high government official or politician.

These indicators are the most used in the literature and we will use them in our baseline estimates. Appendix Table A1 presents the correlations between the different conflict and political variables. While some variables are highly correlated, the vast majority of them have low degrees of correlation (less than 0.3 ), providing some comfort that they provide additional information when used in different equations. This also allows us to cover several dimensions of conflict and political instability.

Third, in robustness checks, we use several other sources including: the International Country Risk Guide (ICRG), Correlates of Wars (COW), the Political Terror Scale of Amnesty International, the Global Terrorism Database (GTD), The Major Episodes of Political Violence Database (Marshall, 2017), the Coup d'Etat Events Database (Marshall and Marshall, 2018) and the State Fragility Index (Marshall and Marshall, 2017) (see appendix A2).

Regarding the remaining control variables, they are from different sources. We extract the real exchange rate, inflation rate, external debt in percentage of GDP, GDP per-capita, real GDP 
growth, and terms of trade from the IMF's World Economic Outlook database. The data on M2/reserves and credit growth are from the World Bank's World Development Indicators. We finally draw the data on the degree of democracy from the Polity IV Project (Marshall and Gurr, 2018).

\section{B. Stylized Facts}

Figure 2 displays the relationship between the number of countries in banking crises and in conflict. It shows a positive relationship between the occurrence of conflict and banking crises and provides evidence that major waves of conflict tend to be associated with a higher rate of occurrence of banking crises.

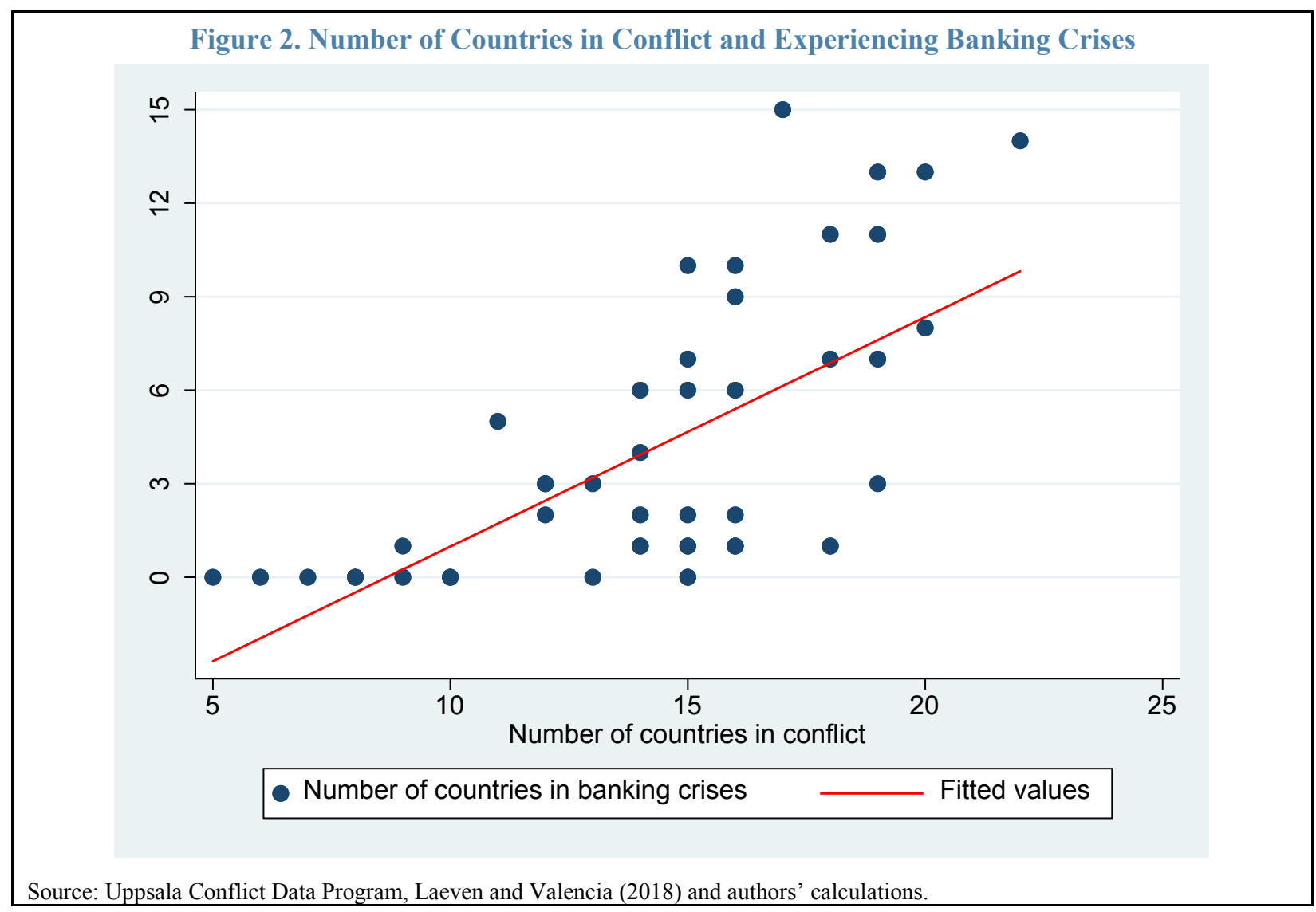

Table 1 presents the unconditional and conditional probabilities of a banking crisis for all conflict and political instability variables included in our baseline estimates. For each variable, we present the number of observations, the number of banking crises and the probability of a banking crisis. Column (3) considers the sample for all country-year observations and describes the unconditional probability of a banking crisis, which is the proportion of country-year observations identified with a start of a banking crisis. In columns (4) and (5), we report the conditional probability of a banking crisis, which is the proportion of country-year observations during which a banking crisis occurred in the absence of conflict and political instability (column 4 ), and the proportion of conflict and political instability that ended up in a banking crisis (column 5). In column (6), we compute the difference in the conditional probability of a banking crisis in years without a conflict and political instability and years of conflict and political instability, while the p-value of the T-test about the significance of the difference is reported in column (7). In the last column, we report the Pearson chi-squared statistic about the 
independence of the occurrence of banking crises and conflict or political instability. The Pearson test shows that there is a statistically significant relationship between banking crises and conflict or political instability.

As can be observed, the conditional probability of a banking crisis is higher when conflict and political instability occur than in the absence of conflict and political instability. For instance, the conditional probability of a banking crisis in a year without a conflict is 5.3 percent; that probability almost doubles in years of conflict (10 percent). The difference is even stronger if we consider general strikes and political assassinations: the probability of a banking crisis increases from 5.7 percent in years without general strikes and political assassinations to 12.5 and 11.7 percent, respectively, in years of general strikes and political assassinations. The t-test in column (7) shows that the differences are statistically different. The unconditional probability of a banking crisis is around 6.4 percent regardless of the variable considered.

\begin{tabular}{|c|c|c|c|c|c|c|c|}
\hline$(1)$ & $(2)$ & (3) & $(4)$ & (5) & $(6)$ & $(7)$ & $(8)$ \\
\hline & & All & $\begin{array}{c}\text { No conflict or } \\
\text { political instability }\end{array}$ & $\begin{array}{c}\text { Conflict or } \\
\text { political } \\
\text { instability }\end{array}$ & $\begin{array}{l}\text { Difference } \\
((5)-(4))\end{array}$ & $\begin{array}{l}\text { T-test } p \text { - } \\
\text { value }\end{array}$ & $\begin{array}{c}\text { Pearson } \\
\text { chi2 }\end{array}$ \\
\hline \multirow{3}{*}{ Conflict } & Observations & 3026 & 2364 & 662 & & & \\
\hline & Number of banking crises & 191 & 125 & 66 & & & $19.17 * * *$ \\
\hline & Probability of a banking crisis & 6.3 & 5.3 & 10.0 & 4.68 & 0.00 & \\
\hline \multirow{3}{*}{ Cabinet change } & Observations & 2975 & 1768 & 1207 & & & \\
\hline & Number of banking crises & 191 & 88 & 103 & & & $17 * * *$ \\
\hline & Probability of a banking crisis & 6.4 & 5.0 & 8.5 & 3.56 & 0.00 & \\
\hline \multirow{3}{*}{$\begin{array}{l}\text { Change in effective } \\
\text { executive }\end{array}$} & Observations & 2975 & 2532 & 443 & & & \\
\hline & Number of banking crises & 191 & 151 & 40 & & & $8.08^{*}$ \\
\hline & Probability of a banking crisis & 6.4 & 6.0 & 9.0 & 3.07 & 0.02 & \\
\hline \multirow{3}{*}{$\begin{array}{l}\text { Anti-government } \\
\text { demonstrations }\end{array}$} & Observations & 2994 & 2160 & 834 & & & \\
\hline & Number of banking crises & 191 & 115 & 76 & & & $54.61 * *$ \\
\hline & Probability of a banking crisis & 6.4 & 5.3 & 9.1 & 3.79 & 0.00 & \\
\hline \multirow{3}{*}{ Government crises } & Observations & 2994 & 2679 & 315 & & & \\
\hline & Number of banking crises & 191 & 158 & 33 & & & $16.03 * * *$ \\
\hline & Probability of a banking crisis & 6.4 & 5.9 & 10.5 & 4.58 & 0.00 & \\
\hline \multirow{3}{*}{ General strikes } & Observations & 2994 & 2689 & 305 & & & \\
\hline & Number of banking crises & 191 & 153 & 38 & & & $27.69 * * *$ \\
\hline & Probability of a banking crisis & 6.4 & 5.7 & 12.5 & 6.77 & 0.00 & \\
\hline \multirow{3}{*}{ Assassinations } & Observations & 2994 & 2636 & 358 & & & \\
\hline & Number of banking crises & 191 & 149 & 42 & & & $46.19 * * *$ \\
\hline & Probability of a banking crisis & 6.4 & 5.7 & 11.7 & 6.08 & 0.00 & \\
\hline
\end{tabular}

Table 2 presents the statistics about the occurrence of banking and fiscal crises following a conflict or political instability. In column (3), we report the conditional probability of a banking crisis following a conflict or political instability, which is closely similar to what we reported in column (5) of Table 1 (the small differences are due to missing data). In column (4) and (5), we have the conditional probabilities of a banking crisis following a conflict without the occurrence of fiscal crisis (column 4) and with the occurrence of a fiscal crisis (column 5).

Table 2 shows that the conditional probability of a banking crisis following the simultaneous occurrence of a conflict or political instability and a fiscal crisis is at least three times higher than the conditional probability of a banking crisis following a conflict or political instability but without the occurrence of a fiscal crisis. For instance, the conditional probability of a banking 
crisis after a joint occurrence of a conflict and a fiscal crisis is 16.7 percent, while that probability declines significantly to only 4.2 percent if a fiscal crisis does not materialize following the conflict. Furthermore, the conditional probability of a banking crisis following the occurrence of a conflict or political instability is higher than the conditional probability of a banking crisis after a conflict when a fiscal crisis does not occur (column 3, Table 2) and the unconditional probability of a banking crisis (column 3 , Table 1 ).

\begin{tabular}{|c|c|c|c|c|c|c|c|}
\hline$(1)$ & $(2)$ & (3) & (4) & $(5)$ & $(6)$ & $(7)$ & $(8)$ \\
\hline & & All & No fiscal crisis & Fiscal crisis & $\begin{array}{c}\text { Difference } \\
((5)-(4))\end{array}$ & $\begin{array}{c}\text { T-test } p \text { - } \\
\text { value }\end{array}$ & $\begin{array}{c}\text { Pearson } \\
\text { chi2 }\end{array}$ \\
\hline \multirow{3}{*}{ Conflict } & Observations & 641 & 330 & 311 & & & \multirow{3}{*}{$26.98^{* * *}$} \\
\hline & Number of banking crises & 66 & 14 & 52 & & & \\
\hline & Probability of a banking crisis & 10.3 & 4.2 & 16.7 & 12.48 & 0.00 & \\
\hline \multirow{3}{*}{ Cabinet change } & Observations & 1176 & 583 & 593 & & & \multirow{3}{*}{$32.05 * * *$} \\
\hline & Number of banking crises & 102 & 24 & 78 & & & \\
\hline & Probability of a banking crisis & 8.7 & 4.1 & 13.2 & 9.04 & 0.00 & \\
\hline \multirow{3}{*}{$\begin{array}{l}\text { Change in effective } \\
\text { executive }\end{array}$} & Observations & 425 & 232 & 193 & & & \multirow{3}{*}{$19.06^{* * *}$} \\
\hline & Number of banking crises & 39 & 9 & 30 & & & \\
\hline & Probability of a banking crisis & 9.2 & 3.9 & 15.5 & 11.66 & 0.00 & \\
\hline \multirow{3}{*}{$\begin{array}{l}\text { Anti-government } \\
\text { demonstrations }\end{array}$} & Observations & 783 & 441 & 342 & & & \multirow{3}{*}{$29.52 * * *$} \\
\hline & Number of banking crises & 75 & 20 & 55 & & & \\
\hline & Probability of a banking crisis & 9.6 & 4.5 & 16.1 & 11.55 & 0.00 & \\
\hline \multirow{3}{*}{ Government crises } & Observations & 308 & 146 & 162 & & & \multirow{3}{*}{$16.02 * * *$} \\
\hline & Number of banking crises & 33 & 5 & 28 & & & \\
\hline & Probability of a banking crisis & 10.7 & 3.4 & 17.3 & 13.86 & 0.00 & \\
\hline \multirow{3}{*}{ General strikes } & Observations & 295 & 153 & 142 & & & \multirow{3}{*}{$16.82 * * *$} \\
\hline & Number of banking crises & 38 & 8 & 30 & & & \\
\hline & Probability of a banking crisis & 12.9 & 5.2 & 21.1 & 15.90 & 0.00 & \\
\hline \multirow{3}{*}{ Assassinations } & Observations & 353 & 161 & 192 & & & \multirow{3}{*}{$19.65^{* * *}$} \\
\hline & Number of banking crises & 42 & 6 & 36 & & & \\
\hline & Probability of a banking crisis & 11.9 & 3.7 & 18.8 & 15.02 & 0.00 & \\
\hline
\end{tabular}

\section{EMPIRICAL STRATEgY}

The empirical specification used in this paper consists of a binary outcome model given that the dependent variable equals to 1 for all observations in the data for which a banking crisis happens, and 0 for the remaining ones (non-occurrence of a banking crisis). The binary response model is written as follows:

$$
\operatorname{Pr}\left(Y_{i t}=1 \mid X_{i t-1}, C_{i}\right)=F\left(X_{i t-1} \beta+C_{i}\right)=X_{i t-1} \beta+C_{i}+\varepsilon_{i t}
$$

where $Y_{i t}$ is a binary response variable taking the value of 1 if there is a banking crisis in a given country $i$ at time $t ; X_{i t-1}$ is a vector of observed explanatory variables including conflict and political instability; $\beta$ is a vector of parameters, $C_{i}$ is an unobserved time-invariant country fixed effect, and $\varepsilon_{i t}$ is the error term with a zero-mean residual uncorrelated with all the terms on the right-hand side. We lag all control variable by one year to avoid the problem of simultaneity and endogeneity ${ }^{3}$.

\footnotetext{
${ }^{3}$ The results remain consistent even if we lag the control variables by up to five years.
} 
The composite error term in (1), $C_{i}+\varepsilon_{i t}$, is an important feature of panel data models. $C_{i}$, also called country-specific heterogeneity, includes historical factors that can affect the probability of experiencing a banking crisis. The key issue is whether the unobserved heterogeneity can be assumed to be independent, or at least uncorrelated, with the observed covariates $X_{i t}$. A usual assumption is that the set of explanatory variables $X_{i t}$ is contemporaneously exogenous conditional on $C_{i}: E\left(\varepsilon_{i t} \mid X_{i t}, C_{i}\right)=0, \mathrm{t}=1, \ldots, \mathrm{T}$. However, this assumption is difficult to be proven valid. In fact, country-specific factors such as religion, language, regulatory framework (common or civil law), and ethnic diversity have been widely shown to affect the degree of economic development and growth (see Barro and McCleary, 2003; Campante and Yanagizawa-Drot, 2015; Mahoney, 2001; Alesina and La Ferrara, 2005; Montalvo and Reynal-Querol, 2005). Given that economic growth is among the explanatory variables, thus the uncorrelation hypothesis between the time-invariant factors and the explanatory variables is violated. Moreover, treating the timeinvariant factors $C_{i}$ as parameters to estimate causes inconsistency in $\beta$ because of the incidental parameters problem (Neyman and Scott, 1948; Lancaster, 2000).

The fixed effects approach could be used to estimate equation (1). The most appealing reason is that by controlling out the time invariant variables, the model accounts for biases that occur with omitted and unobserved variables. Unfortunately, the power of the fixed effects approach results in an undesirable consequence: even where we do have data for time invariant variables, that information is excluded from the model. In addition, as noted by Caballero (2014), Eberhardt and Presbitero (2018), and Kinda et al. (2016), all countries that have not experienced banking crises will be excluded from the estimates. In our sample, 40 percent of countries (37 out of 92) have not experienced at all banking crises over our study period 1970-2017. Excluding these countries from the estimates raises the issue of selection bias and inconsistent results. As argued by Bell and Jones (2015), the fixed effects models are only modelling one part of the data structure, the within-country effects at the expense of between-country effects.

Mundlak (1978) provides a method by which it is possible to incorporate both the time-invariant variables with the demeaned coefficients from the fixed effects model and at the same time use the framework of a random effects model (hence a hybrid model). This method, called the correlated random effects, assumes that the unobserved heterogeneity is a function of the country-level time averages of $X_{i t}$, which we denote as $\bar{X}_{l}$. That is, $C_{i}=\omega+\bar{X}_{l} \delta+a_{i}$, where $\bar{X}_{l}$ is an average of $X_{i t}$ over time for country $i$ (hence time invariant); $a_{i}$ is assumed uncorrelated with $\bar{X}_{l}$ and normally distributed. Therefore, the random effects-Mundlak (1978) model allows for modeling the distribution of the omitted variable conditional on the means of the strictly exogenous variables, instead of treating the omitted variable as a parameter to estimate. The probability that $Y_{i t}=1$ can now be written as:

$$
\begin{aligned}
& \operatorname{Pr}\left(Y_{i t}=1 \mid X_{i t}, C_{i}\right)=\operatorname{Pr}\left(Y_{i t}=1 \mid X_{i t}, \bar{X}_{l}, C_{i}\right) \\
& =F\left(X_{i t} \beta+\omega+\bar{X}_{\imath} \delta+a_{i}\right)=X_{i t} \beta+\bar{X}_{l} \delta+a_{i}+\varepsilon_{i t}
\end{aligned}
$$

In this paper, we employ the random effects-Mundlak model by including the means of all time-varying covariates for the countries in the estimates. These averages have the same value for a given country across years but vary across countries. By including the vector of time-averaged variables, we still control for time-constant unobserved heterogeneity, as with fixed effects, while avoiding the problem of incidental parameters in nonlinear models. At the same time, the Mundlak model allows measurement of the effects of time-constant independent variables, just as in a traditional random effects model (Wooldridge, 2010). Therefore, by taking care of all country-specific and time-invariant characteristics that may affect the likelihood of a crisis or the 
occurrence of conflict and political instability, or both, the Mundlak model allows for differences within and between-country effects (Caballero, 2014). Contrary to the simple fixed effects model which excludes all countries that have not experienced banking crises from the sample, the random effects-Mundlak model takes into account all these countries in the estimates.

In robust checks, we use the traditional probit and logit models, as well as the probit fixed-effects model of Fernández-Val and Weidner (2016). The approach by Fernández-Val and Weidner (2016) accounts for the bias arising from the inclusion of country fixed-effects and corrects for the incident parameter bias problem by subtracting from the maximum likelihood estimator a plug-in estimator of the bias. As explained above, the main drawback of this method is that it excludes all countries that have not experienced banking crises.

Relying on the extensive literature on the determinants of banking crises, we control for a number of variables:

- Real effective exchange rate: the literature shows that a sharp decline in the real exchange rate is associated with a greater risk of banking system distress (De Bock and Demyanets, 2012; Kaminsky and Reinhart, 1999; Reinhart et al., 2000). For instance, De Bock and Demyanets (2012) found that exchange rate depreciation implies increasing rates of NPLs and banking turmoil on a sample of 25 emerging markets over 1996-2010. Hence, we expect a depreciation of the real exchange rate to be positively associated with an increase in the likelihood of a banking crisis.

- M2/reserves: it measures banks' exposure to foreign exchange risk and a country's vulnerability to currency crises which often coincide with banking crises (Davis and Stone, 2004; Kinda et al., 2016). Thus, we expect a positive correlation between $\mathrm{M} 2 /$ reserves and banking crises.

- Inflation: we include this variable to capture macroeconomic mismanagement as previous studies clearly evidenced that high rates of inflation are associated with banking crises (Demirgüç-Kunt and Detragiache, 1998-2000; Davis et al., 2011; Joyce, 2011). High inflation tends to undermine the long-run economic growth and distorts macroeconomic and financial stability. Therefore, a positive correlation between inflation and banking crises is expected.

- Credit growth: an important body of the literature argues that high credit growth is conductive to banking sector problems (Cihák, 2007; Joyce, 2011; Acosta-Gonzalez et al., 2011). For instance, Beck et al. (2006) underline that a credit boom could induce an asset price bubble that may cause a crisis when it bursts. Moreover, Büyükkarabacak and Valev (2010) provided evidence that a rapid credit boom generates vulnerabilities that increase the probability of a banking crisis. However, a few studies including Von Hagen and Ho (2007) and Rose and Spiegel (2011) do not find evidence that a boom in the credit-to-GDP ratio is associated with greater probability of a banking crisis.

- External debt: high debt-to-GDP ratio indicates greater tighter financial conditions and reduced fiscal space (Kinda et al., 2016) and is likely to lead a banking crisis. In countries where banks are the main holders of government debt, worsened financial conditions or sovereign debt defaults would undoubtedly weaken banks' balance sheets. Moreover, heavily-indebted economies are more likely to face high risk premiums in international 
capital markets. As a result, government capacity to intervene in case of banking liquidity shortage become very limited. We expect a positive correlation between external debt and the likelihood of a banking crisis.

- GDP per capita: it captures the level of development in a country. Some studies (Demirgüç-Kunt and Detragiache, 2000-2005; Kinda et al. 2016) found that banking crises are negatively associated with real GDP per capita.

- GDP growth: according to the literature, deteriorating growth prospects are associated with greater risk of banking crises as lower economic growth negatively affects banks' balance sheets by increasing the share of non-performing loans (Klomp, 2010). Some studies found that in most cases, banking crises followed an episode of growth slowdown (Demirgüç-Kunt and Detragiache, 1998-2005; Von Hagen and Ho, 2007; Angkinand and Willett, 2011). We thus expect a negative association between economic growth and banking crises.

- Terms of trade: a deterioration of the terms of trade reduces the ability of banks' customers to service their financial commitments, leading to an increase of NPLs and rendering banking crises more likely (Goldstein and Turner, 1996; Caprio and Klingebiel, 1999). Hence, we expect a negative correlation between terms of trade and banking crises.

- Degree of democracy: it refers to the quality of the politico-institutional environment and is expected to be negatively associated with the occurrence of a banking crisis. Countries with good institutions and governance tend to implement sound financial regulations to promote banking system stability that can potentially in turn reduce the probability of banking crises (Francis, 2003; Beck et al., 2006). In addition, financial fraud and excessive risk-taking in weak institutional countries increase the vulnerability of the banking sector and result in bank collapses (Kinda et al., 2016). A negative correlation between the degree of democracy and the likelihood of a banking crisis is expected.

\section{EMPIRICAL RESULTS}

\section{A. Baseline Results}

The baseline evidence on the relationship between conflicts, political instability and banking crises is reported in Table 3. We present in each column the results obtained through the estimates of equation (2) employing the random effect model of Mundlak (1978) and using several indicators of conflicts and political instability. The first two columns are about the effects of conflicts, while the remaining columns deal with the effects of political instability. In column (1), we use a binary variable taking the value of 1 if the country experiences a conflict and 0 otherwise. The results show that the coefficient associated with this binary variable is positive and statistically significant at the 1 percent level. This finding suggests that being in conflict affects positively the likelihood of occurrence of banking crises.

The test statistics suggest that the Mundlak (1978) approach used in the estimates is accurate and that the model classifies properly the group of countries that experienced banking crises and those that did not experience banking crises. We report at the bottom of the table the area under the ROC curve (AUROC) statistics and their standard errors to test the goodness of fit of the 
model. The AUROC statistic is between 0 and 1 , with higher values representing a strong performance of the model. In Table 3, the AUROC statistic is above 0.73 in all the columns.

To give an idea about the magnitude, we follow Caballero (2014) in analyzing our results in terms of odds ratios. Given that we are using a logit model, the odds ratios are the exponentiated values of the coefficients reported in Table 3. Therefore, based on the results in column (1), the odds of a banking crisis are 2.5 times greater when a country is affected by a conflict. The probability of experiencing a banking crisis raises from 6.3 percent (unconditional probability) to 13.5 percent when a country is in conflict. ${ }^{4}$ In column (2), we use the intensity of conflict instead of the binary variable used in column (1). The results remain consistent as the coefficient associated with conflict is positive and significant at the 1 percent level.

Turning to the effects of political instability, we present in column 3 the results when we use the change in government cabinet as an indicator of political instability following Alesina et al. (1996) and Aisen and Veiga (2013). We find that the coefficient associated with the variable cabinet changes is positive and highly significant at the 1 percent level. That said, political instability is correlated with a higher occurrence of banking crises. Quantitatively, an increase in the number of cabinet changes from zero to four (which is the maximum observed in the sample) is associated with an increase in the likelihood of banking crises to 21.17 percent, from the unconditional probability of experiencing a banking crisis of 6.3 percent.

In columns 4, we use the number of changes in effective executive as a proxy of political instability (Alesina et al. 1996). We find a positive correlation between the number of changes in effective executive and the occurrence of banking crises. In the remaining columns, we use the number of anti-governmental demonstrations, government crises, general strikes and political assassinations as proxies of political instability. We still find that the coefficients associated with these variables are positive and significant, although the level of significance differs between columns.

\footnotetext{
4 The odds are the ratio of the probability of a positive outcome to the probability of a no positive outcome: odds $=$ $p / q$, where $q=1-p$ and $p=\operatorname{Pr}(Y=1 \mid X)$. In our sample, the unconditional probability of a crisis is 6.3 percent (191 crises out of 3,026 observations), implying that the odds(crisis) is 0.0631 . In column 1 of Table 3 , the odds of a crisis, conditional on the occurrence of a conflict, increase by 2.5 times (this is the exponential of the coefficient associated with conflict: 0.9097$)$. Then, the estimated conditional probability of a crisis is $0.1355=\left(2.5^{*} 0.0631\right) /[1$ $+(2.5 * 0.0631)]$. All analyzes in the subsequent sections follow this methodology.
} 


\begin{tabular}{|c|c|c|c|c|c|c|c|c|}
\hline \multicolumn{9}{|c|}{ Table 3. Baseline Results } \\
\hline \multirow[t]{2}{*}{ VARIABLES } & (1) & (2) & (3) & (4) & (5) & (6) & (7) & (8) \\
\hline & $\begin{array}{l}\text { Conflict } \\
\text { (binary) }\end{array}$ & $\begin{array}{c}\text { Conflict } \\
\text { (intensity) }\end{array}$ & $\begin{array}{l}\text { Cabinet } \\
\text { changes }\end{array}$ & $\begin{array}{l}\text { Changes in } \\
\text { Effective } \\
\text { Executive }\end{array}$ & $\begin{array}{l}\text { Anti-Government } \\
\text { Demonstrations }\end{array}$ & $\begin{array}{l}\text { Government } \\
\text { Crises }\end{array}$ & $\begin{array}{l}\text { General } \\
\text { Strikes }\end{array}$ & Assassinations \\
\hline Variable in column $(\mathrm{X}), \mathrm{t}-1$ & $\begin{array}{c}0.9097 * * * \\
(0.245)\end{array}$ & $\begin{array}{c}0.4483^{* * * *} \\
(0.167)\end{array}$ & $\begin{array}{c}0.3620^{* * * *} \\
(0.126)\end{array}$ & $\begin{array}{c}0.3277^{* *} \\
(0.150)\end{array}$ & $\begin{array}{c}0.0295^{*} \\
(0.017)\end{array}$ & $\begin{array}{c}0.2894 * * \\
(0.134)\end{array}$ & $\begin{array}{c}0.2211^{* *} \\
(0.094)\end{array}$ & $\begin{array}{c}0.0788^{*} \\
(0.042)\end{array}$ \\
\hline Exchange rate, $\mathrm{t}-1$ & $\begin{array}{c}-0.0903^{* *} \\
(0.039)\end{array}$ & $\begin{array}{c}-0.0892^{* *} \\
(0.039)\end{array}$ & $\begin{array}{c}-0.0931^{* *} \\
(0.039)\end{array}$ & $\begin{array}{c}-0.0959 * * \\
(0.039)\end{array}$ & $\begin{array}{c}-0.0910^{* *} \\
(0.039)\end{array}$ & $\begin{array}{c}-0.1024 * * \\
(0.040)\end{array}$ & $\begin{array}{c}-0.0987^{* *} \\
(0.039)\end{array}$ & $\begin{array}{c}-0.0899 * * \\
(0.039)\end{array}$ \\
\hline $\mathrm{M} 2 /$ reserves, $\mathrm{t}-1$ & $\begin{array}{c}0.5660 * * * \\
(0.124)\end{array}$ & $\begin{array}{c}0.5531 * * * \\
(0.124)\end{array}$ & $\begin{array}{c}0.5605 * * * \\
(0.123)\end{array}$ & $\begin{array}{c}0.5658 * * * \\
(0.123)\end{array}$ & $\begin{array}{c}0.5691 * * * \\
(0.123)\end{array}$ & $\begin{array}{c}0.5675^{* * *} \\
(0.123)\end{array}$ & $\begin{array}{c}0.5666 * * * \\
(0.123)\end{array}$ & $\begin{array}{c}0.5675^{* * *} \\
(0.123)\end{array}$ \\
\hline Inflation, $\mathrm{t}-1$ & $\begin{array}{c}1.0096 * * * \\
(0.172)\end{array}$ & $\begin{array}{c}1.0140^{* * *} \\
(0.173)\end{array}$ & $\begin{array}{c}1.0163^{* * *} \\
(0.169)\end{array}$ & $\begin{array}{c}1.0224 * * * \\
(0.172)\end{array}$ & $\begin{array}{c}1.0509^{* * *} \\
(0.170)\end{array}$ & $\begin{array}{c}1.0638^{* * *} \\
(0.172)\end{array}$ & $\begin{array}{c}1.0106^{* * *} \\
(0.172)\end{array}$ & $\begin{array}{c}1.0148^{* * *} \\
(0.172)\end{array}$ \\
\hline Credit growth, $\mathrm{t}-1$ & $\begin{array}{c}0.4867^{*} \\
(0.293)\end{array}$ & $\begin{array}{l}0.3878 \\
(0.286)\end{array}$ & $\begin{array}{l}0.3468 \\
(0.281)\end{array}$ & $\begin{array}{l}0.2923 \\
(0.281)\end{array}$ & $\begin{array}{l}0.3007 \\
(0.280)\end{array}$ & $\begin{array}{l}0.3571 \\
(0.283)\end{array}$ & $\begin{array}{l}0.2995 \\
(0.280)\end{array}$ & $\begin{array}{l}0.3088 \\
(0.281)\end{array}$ \\
\hline External debt, t-1 & $\begin{array}{c}0.7992 * * * \\
(0.144)\end{array}$ & $\begin{array}{c}0.7981 * * * \\
(0.145)\end{array}$ & $\begin{array}{c}0.8284 * * * \\
(0.144)\end{array}$ & $\begin{array}{c}0.8410 * * * \\
(0.144)\end{array}$ & $\begin{array}{c}0.8267 * * * \\
(0.144)\end{array}$ & $\begin{array}{c}0.8388^{* * *} \\
(0.144)\end{array}$ & $\begin{array}{c}0.8137 * * * \\
(0.144)\end{array}$ & $\begin{array}{c}0.8282 * * * \\
(0.144)\end{array}$ \\
\hline GDP per capita, t-1 & $\begin{array}{r}-0.3966 \\
(0.315)\end{array}$ & $\begin{array}{r}-0.3913 \\
(0.317)\end{array}$ & $\begin{array}{r}-0.3530 \\
(0.318)\end{array}$ & $\begin{array}{r}-0.3983 \\
(0.316)\end{array}$ & $\begin{array}{c}-0.4916 \\
(0.317)\end{array}$ & $\begin{array}{c}-0.3989 \\
(0.316)\end{array}$ & $\begin{array}{r}-0.4452 \\
(0.313)\end{array}$ & $\begin{array}{c}-0.4245 \\
(0.317)\end{array}$ \\
\hline Economic growth, t-1 & $\begin{array}{c}-0.0324^{*} \\
(0.019)\end{array}$ & $\begin{array}{l}-0.0312 \\
(0.019)\end{array}$ & $\begin{array}{l}-0.0257 \\
(0.019)\end{array}$ & $\begin{array}{l}-0.0277 \\
(0.019)\end{array}$ & $\begin{array}{c}-0.0324^{*} \\
(0.019)\end{array}$ & $\begin{array}{c}-0.0289 \\
(0.020)\end{array}$ & $\begin{array}{c}-0.0331^{*} \\
(0.019)\end{array}$ & $\begin{array}{c}-0.0340^{*} \\
(0.019)\end{array}$ \\
\hline Terms of trade, $\mathrm{t}-1$ & $\begin{array}{l}0.0286 \\
(1.206)\end{array}$ & $\begin{array}{l}0.0910 \\
(1.207)\end{array}$ & $\begin{array}{l}-0.1673 \\
(1.218)\end{array}$ & $\begin{array}{l}-0.0626 \\
(1.218)\end{array}$ & $\begin{array}{l}0.0235 \\
(1.206)\end{array}$ & $\begin{array}{l}-0.0540 \\
(1.210)\end{array}$ & $\begin{array}{l}0.0422 \\
(1.204)\end{array}$ & $\begin{array}{c}-0.0172 \\
(1.210)\end{array}$ \\
\hline Degree of democracy, $\mathrm{t}-1$ & $\begin{array}{c}-0.0460^{* *} \\
(0.019)\end{array}$ & $\begin{array}{c}-0.0469^{* *} \\
(0.019)\end{array}$ & $\begin{array}{c}-0.0524 * * * \\
(0.019)\end{array}$ & $\begin{array}{c}-0.0540^{* * *} \\
(0.019)\end{array}$ & $\begin{array}{c}-0.0466^{* *} \\
(0.019)\end{array}$ & $\begin{array}{c}-0.0514 * * * \\
(0.019)\end{array}$ & $\begin{array}{c}-0.0518^{* * *} \\
(0.019)\end{array}$ & $\begin{array}{c}-0.0483^{* * *} \\
(0.019)\end{array}$ \\
\hline Observations & 3,026 & 3,026 & 2,972 & 2,972 & 2,991 & 2,991 & 2,991 & 2,991 \\
\hline Number of countries & 92 & 92 & 92 & 92 & 92 & 92 & 92 & 92 \\
\hline Log likelihood & -598.7 & -602.1 & -599.5 & -600.6 & -603.3 & -602.4 & -602.2 & -603.1 \\
\hline Wald chi2 & 326.9 & 323.8 & 335.6 & 333.5 & 327.5 & 328.1 & 335 & 323.8 \\
\hline Rho(LR) & 0.482 & 0.484 & 0.460 & 0.457 & 0.471 & 0.469 & 0.465 & 0.476 \\
\hline P-value(Rho) & 0 & 0 & 0 & 0 & 0 & 0 & 0 & 0 \\
\hline AUROC & 0.751 & 0.744 & 0.742 & 0.739 & 0.734 & 0.734 & 0.740 & 0.737 \\
\hline seAUROC & 0.0174 & 0.0174 & 0.0175 & 0.0183 & 0.0181 & 0.0178 & 0.0177 & 0.0177 \\
\hline
\end{tabular}

Figure 3 presents the predicted values of the likelihood of banking crises for different levels of conflict probability and intensity, and political instability. The predicted values are obtained from the regressions in Table 3 . The blue lines represent the predicted probability of a banking crisis given the probability of a conflict (panel 3.A), the intensity of conflict (panel 3. B) or the intensity of political instability (panel 3. C-H). The dashed lines indicate the 95 confidence intervals. Figure 3 shows clearly that the higher the likelihood or intensity of conflict and political instability, the higher the likelihood of experiencing a banking crisis.

Regarding the remaining control variables, with a few exceptions, they are significant and consistent with the literature. We find that the coefficients associated with M2/reserves, inflation, credit growth, and external debt are all positively correlated with banking crises. It has been shown that an increase in broad money compared to the level of reserves is positively associated with a high occurrence of banking crises (Demirgüç-Kunt and Detragiache, 2000-2005; Davis and Stone, 2004; Von Hagen and Ho, 2007; Kinda et al., 2016). High inflation rates negatively affect the banking sector stability (Davis et al., 2011 and Joyce, 2011), while mounting debt level is often considered as a predictor of banks failures. 


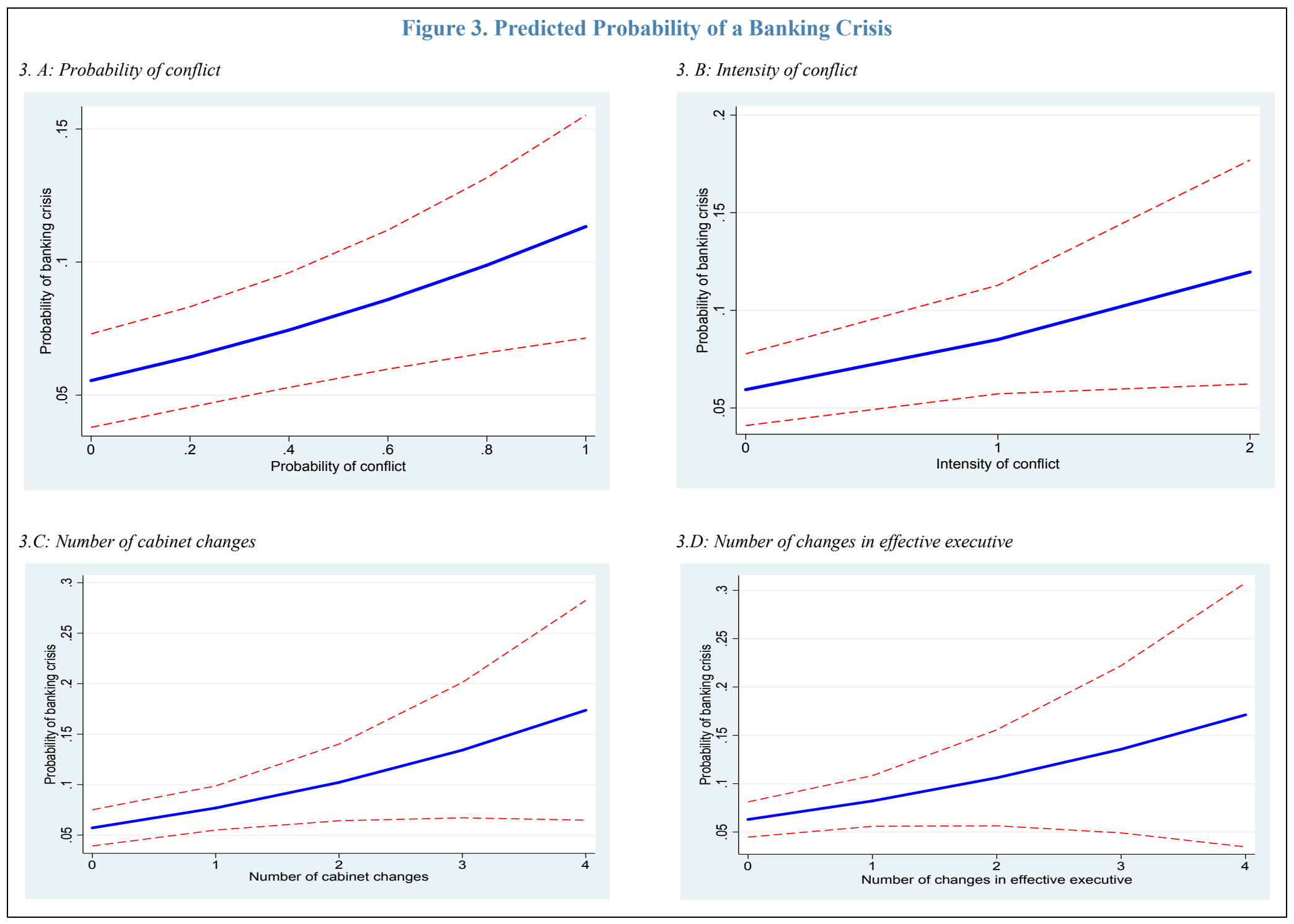




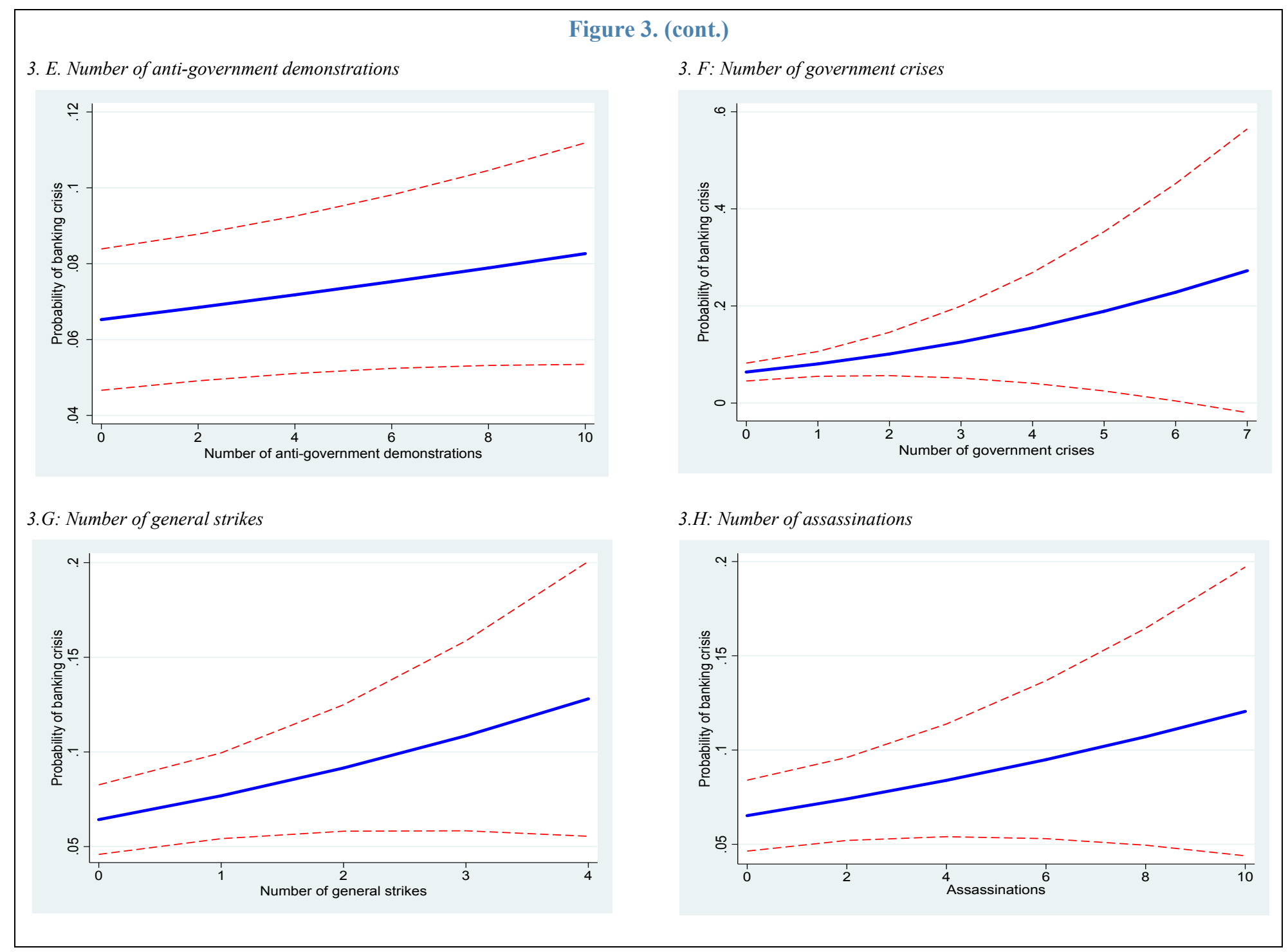


On the other hand, the coefficients associated with exchange rate, economic growth, and the degree of democracy are negatively associated with banking crises. As shown in the literature, a depreciation of the exchange rate can potentially lead to a banking crisis (Reinhart et al., 2000; Duttagupta and Cashin, 2011; De Bock and Demyanets, 2012). A sound politico-institutional environment is less favorable to the occurrence of banking turmoil (Beck et al., 2006; Kinda et al., 2016). However, as in Demirgüç-Kunt and Detragiache (2000), the level of development measured by the GDP per capita is not statistically significant. Similarly, the terms of trade are found to be a non-significant determinant of banking crisis.

Table 4 reports the results when we split the sample into two subsamples: emerging markets and low-income countries, following the IMF classification of countries. The results show that conflict and political instability are a predictor of banking crises in both emerging economies and low-income economies. However, the results differ slightly between the two group of countries. For emerging markets, the coefficients associated with conflict and political instability variables are all positive and significant in all columns, except for government crises and political assassinations. For low-income countries, all coefficients are positive and significant, except those associated with effective changes in the executive, anti-government demonstrations, and general strikes. Considering the case of conflict, its effect on banking crises is higher in low-income countries than in emerging markets. The probability of experiencing a banking crisis increases to 14.12 percent when an emerging market is hit by a conflict, while that probability jumps to 17.15 percent in a low-income country.

\begin{tabular}{|c|c|c|c|c|c|c|c|c|}
\hline \multirow[t]{3}{*}{ VARIABLES } & (1) & $(2)$ & (3) & (4) & (5) & (6) & (7) & (8) \\
\hline & $\begin{array}{l}\text { Conflict } \\
\text { (binary) }\end{array}$ & $\begin{array}{l}\text { Conflict } \\
\text { (intensity) }\end{array}$ & $\begin{array}{l}\text { Cabinet } \\
\text { changes }\end{array}$ & $\begin{array}{l}\text { Changes in Effective } \\
\text { Executive }\end{array}$ & $\begin{array}{l}\text { Anti-Government } \\
\text { Demonstrations }\end{array}$ & $\begin{array}{l}\text { Government } \\
\text { Crises }\end{array}$ & General Strikes & Assassinati \\
\hline & \multicolumn{8}{|c|}{ Emerging countries } \\
\hline Variable in column $(\mathrm{X}), \mathrm{t}-1$ & $\begin{array}{c}0.9573 * * * \\
(0.347)\end{array}$ & $\begin{array}{c}0.5454^{* *} \\
(0.230)\end{array}$ & $\begin{array}{c}0.3021^{*} \\
(0.163)\end{array}$ & $\begin{array}{l}0.3582^{*} \\
(0.190)\end{array}$ & $\begin{array}{c}0.0551^{*} \\
(0.030)\end{array}$ & $\begin{array}{l}0.1899 \\
(0.153)\end{array}$ & $\begin{array}{c}0.2515^{* *} \\
(0.111)\end{array}$ & $\begin{array}{l}0.0412 \\
(0.053)\end{array}$ \\
\hline Observations & 1,638 & 1,638 & 1,637 & 1,637 & 1,637 & 1,637 & 1,637 & 1,637 \\
\hline Number of countries & 49 & 49 & 49 & 49 & 49 & 49 & 49 & 49 \\
\hline Log likelihood & -366.1 & -367.2 & -368 & -367.9 & -368.5 & -368.6 & -367.5 & -369.6 \\
\hline Wald chi2 & 196.7 & 193.4 & 209.1 & 203 & 200.2 & 202.5 & 211.7 & 196.2 \\
\hline Rho(LR) & 0.438 & 0.444 & 0.403 & 0.421 & 0.424 & 0.411 & 0.407 & 0.430 \\
\hline P-value(Rho) & 0 & 0 & 0 & 0 & 0 & 0 & 0 & 0 \\
\hline AUROC & 0.743 & 0.737 & 0.727 & 0.734 & 0.727 & 0.726 & 0.729 & 0.730 \\
\hline \multirow[t]{2}{*}{ seAUROC } & 0.0173 & 0.0171 & 0.0176 & 0.0178 & 0.0174 & 0.0174 & 0.0174 & 0.0174 \\
\hline & \multicolumn{8}{|c|}{ Low-income developing countries } \\
\hline Variable in column $(\mathrm{X}), \mathrm{t}-1$ & $\begin{array}{c}1.1874 * * * \\
(0.368)\end{array}$ & $\begin{array}{c}0.4909^{*} \\
(0.272)\end{array}$ & $\begin{array}{c}0.4627^{* *} \\
(0.211)\end{array}$ & $\begin{array}{l}0.2014 \\
(0.270)\end{array}$ & $\begin{array}{l}0.0478 \\
(0.043)\end{array}$ & $\begin{array}{c}0.7460^{* *} \\
(0.341)\end{array}$ & $\begin{array}{l}0.2996 \\
(0.207)\end{array}$ & $\begin{array}{r}0.2972 * \\
(0.089)\end{array}$ \\
\hline Observations & 1,306 & 1,306 & 1,253 & 1,253 & 1,272 & 1,272 & 1,272 & 1,272 \\
\hline Number of countries & 43 & 43 & 43 & 43 & 43 & 43 & 43 & 43 \\
\hline Log likelihood & -210.5 & -213.8 & -209.1 & -213.6 & -213.8 & -212.2 & -213.4 & -210.4 \\
\hline Wald chi2 & 139.2 & 135.4 & 145 & 134.3 & 134.9 & 138.8 & 135.3 & 139.4 \\
\hline Rho(LR) & 0.474 & 0.477 & 0.400 & 0.452 & 0.458 & 0.452 & 0.458 & 0.460 \\
\hline P-value(Rho) & 0 & 0 & 0 & 0 & 0 & 0 & 0 & 0 \\
\hline AUROC & 0.656 & 0.642 & 0.642 & 0.648 & 0.638 & 0.645 & 0.646 & 0.651 \\
\hline seAUROC & 0.0213 & 0.0215 & 0.0216 & 0.0211 & 0.0213 & 0.0213 & 0.0213 & 0.0213 \\
\hline Control variables & Yes & Yes & Yes & Yes & Yes & Yes & Yes & Yes \\
\hline
\end{tabular}




\section{B. Do Conflicts and Political Instability in Neighboring Countries Matter?}

In this subsection, we assess whether conflicts and political instability in neighboring countries affect the likelihood of experiencing a banking crisis in a given country. Such spillover effects can occur as banks perform their activities in bordering countries in search of portfolio diversification and the last two decades have been marked by an increase in financial globalization (Mishkin, 2007; Kose et al. 2006). Previous studies have shown that conflicts in bordering countries matter. For instance, Qureshi (2013) found a significant negative effect of both intrastate and international conflicts on the bilateral trade of neighboring countries that may not be directly involved in any conflict. Murdoch and Sandler (2004) and De Groot (2010) highlighted that conflicts have negative spillover effects on neighboring countries by inducing a significant decline on output growth in the short-run.

We define the variables of conflicts and political instability in neighboring countries as follows. For conflict, we define two variables: one being the number of bordering countries in conflict and another being the simple average of conflict intensity in bordering countries. For political instability variables, we generated the simple average of the number of cabinet changes, changes in effective executive, anti-government demonstrations, government crises, general strikes and political assassinations in bordering countries. We then run the same regressions as in Table 3.

The results are reported in Table 5. We find that the coefficients associated with our variables of interest are positive and statistically significant in columns 1-4, although the spillover effect is generally lower than the direct one. This suggests that conflicts and political instability in neighboring countries increase the likelihood of banking crises in a given country. More specifically, for a given country, an increase in the number and intensity of conflict, and the number of changes in government cabinet and effective executive and the number of general strikes in bordering countries are associated with an increase in its probability to experience a banking crisis.

For instance, if we focus on column (1), a rise in the number of bordering countries affected by conflict from 0 to 3 (which is the median number of bordering countries in conflict) would result in an increase of the likelihood of banking crises from 6.3 percent to 11.2 percent. On the other hand, we find the coefficient associated with the number of anti-government demonstrations, government crises and political assassinations in bordering countries have no significant spillover effects. 


\begin{tabular}{|c|c|c|c|c|c|c|c|c|}
\hline & (1) & (2) & (3) & (4) & (5) & (6) & (7) & (8) \\
\hline VARIABLES & $\begin{array}{c}\text { Conflict (number } \\
\text { of states) }\end{array}$ & Conflict (intensity) & Cabinet changes & $\begin{array}{l}\text { Changes in } \\
\text { Effective } \\
\text { Executive }\end{array}$ & $\begin{array}{l}\text { Anti-Government } \\
\text { Demonstrations }\end{array}$ & $\begin{array}{l}\text { Government } \\
\text { Crises }\end{array}$ & General Strikes & Assassinations \\
\hline Neighbor at war or pol. instability, t-1 & $\begin{array}{c}0.2077^{* * *} \\
(0.060)\end{array}$ & $\begin{array}{c}2.2675^{* * *} \\
(0.735)\end{array}$ & $\begin{array}{c}0.4742^{* *} \\
(0.235)\end{array}$ & $\begin{array}{c}0.7325^{* * * *} \\
(0.262)\end{array}$ & $\begin{array}{l}-0.0171 \\
(0.038)\end{array}$ & $\begin{array}{l}0.1919 \\
(0.156)\end{array}$ & $\begin{array}{l}0.1633 \\
(0.146)\end{array}$ & $\begin{array}{c}-0.0210 \\
(0.064)\end{array}$ \\
\hline Variable in column $(\mathrm{X}), \mathrm{t}-1$ & $\begin{array}{c}0.7820^{* * *} \\
(0.238)\end{array}$ & $\begin{array}{c}0.3618^{* *} \\
(0.163)\end{array}$ & $\begin{array}{c}0.3983 * * * \\
(0.132)\end{array}$ & $\begin{array}{c}0.3027^{*} \\
(0.160)\end{array}$ & $\begin{array}{l}0.0300 \\
(0.019)\end{array}$ & $\begin{array}{c}0.2480^{*} \\
(0.138)\end{array}$ & $\begin{array}{c}0.1869^{*} \\
(0.099)\end{array}$ & $\begin{array}{c}0.0785^{*} \\
(0.043)\end{array}$ \\
\hline Exchange rate, $\mathrm{t}-1$ & $\begin{array}{c}-0.1035^{* *} \\
(0.041)\end{array}$ & $\begin{array}{c}-0.1013^{* *} \\
(0.041)\end{array}$ & $\begin{array}{c}-0.0899^{* *} \\
(0.039)\end{array}$ & $\begin{array}{c}-0.0924 * * \\
(0.039)\end{array}$ & $\begin{array}{c}-0.0878^{* *} \\
(0.039)\end{array}$ & $\begin{array}{c}-0.0989 * * \\
(0.040)\end{array}$ & $\begin{array}{c}-0.0955^{* *} \\
(0.039)\end{array}$ & $\begin{array}{c}-0.0855^{* *} \\
(0.039)\end{array}$ \\
\hline $\mathrm{M} 2 /$ reserves, $\mathrm{t}-1$ & $\begin{array}{c}0.5593 * * * \\
(0.130)\end{array}$ & $\begin{array}{c}0.5543^{* * *} \\
(0.129)\end{array}$ & $\begin{array}{c}0.5673^{* * *} \\
(0.130)\end{array}$ & $\begin{array}{c}0.5758^{* * * *} \\
(0.130)\end{array}$ & $\begin{array}{c}0.5707 * * * \\
(0.130)\end{array}$ & $\begin{array}{c}0.5724 * * * \\
(0.131)\end{array}$ & $\begin{array}{c}0.5705^{* * *} \\
(0.130)\end{array}$ & $\begin{array}{c}0.5772^{* * *} \\
(0.131)\end{array}$ \\
\hline Inflation, t-1 & $\begin{array}{c}0.9740^{* * *} \\
(0.173)\end{array}$ & $\begin{array}{c}0.9838^{* * * *} \\
(0.173)\end{array}$ & $\begin{array}{c}0.9887^{* * *} \\
(0.172)\end{array}$ & $\begin{array}{c}0.9884 * * * \\
(0.176)\end{array}$ & $\begin{array}{c}1.0153^{* * *} \\
(0.172)\end{array}$ & $\begin{array}{c}1.0432 * * * \\
(0.176)\end{array}$ & $\begin{array}{c}0.9819 * * * \\
(0.175)\end{array}$ & $\begin{array}{c}0.9900^{* * *} \\
(0.177)\end{array}$ \\
\hline Credit growth, $\mathrm{t}-1$ & $\begin{array}{l}0.3985 \\
(0.294)\end{array}$ & $\begin{array}{l}0.3132 \\
(0.287)\end{array}$ & $\begin{array}{l}0.3431 \\
(0.290)\end{array}$ & $\begin{array}{l}0.2536 \\
(0.288)\end{array}$ & $\begin{array}{l}0.2684 \\
(0.288)\end{array}$ & $\begin{array}{l}0.3222 \\
(0.291)\end{array}$ & $\begin{array}{l}0.2480 \\
(0.287)\end{array}$ & $\begin{array}{l}0.2771 \\
(0.289)\end{array}$ \\
\hline External debt, $\mathrm{t}-1$ & $\begin{array}{c}0.6859^{* * *} \\
(0.151)\end{array}$ & $\begin{array}{c}0.7398^{* * * *} \\
(0.148)\end{array}$ & $\begin{array}{c}0.7800^{* * *} \\
(0.152)\end{array}$ & $\begin{array}{c}0.8003 * * * \\
(0.152)\end{array}$ & $\begin{array}{c}0.8266^{* * *} \\
(0.152)\end{array}$ & $\begin{array}{c}0.8257 * * * \\
(0.152)\end{array}$ & $\begin{array}{c}0.7702 * * * \\
(0.151)\end{array}$ & $\begin{array}{c}0.8081^{* * *} \\
(0.151)\end{array}$ \\
\hline GDP per capita, $\mathrm{t}-1$ & $\begin{array}{l}0.2945 \\
(0.367)\end{array}$ & $\begin{array}{l}0.3251 \\
(0.380)\end{array}$ & $\begin{array}{c}-0.3198 \\
(0.349)\end{array}$ & $\begin{array}{l}-0.3818 \\
(0.345)\end{array}$ & $\begin{array}{c}-0.4205 \\
(0.350)\end{array}$ & $\begin{array}{l}-0.3571 \\
(0.348)\end{array}$ & $\begin{array}{l}-0.4468 \\
(0.342)\end{array}$ & $\begin{array}{l}-0.4374 \\
(0.348)\end{array}$ \\
\hline Economic growth, t-1 & $\begin{array}{c}-0.0352^{*} \\
(0.019)\end{array}$ & $\begin{array}{c}-0.0327^{*} \\
(0.019)\end{array}$ & $\begin{array}{l}-0.0219 \\
(0.020)\end{array}$ & $\begin{array}{l}-0.0243 \\
(0.020)\end{array}$ & $\begin{array}{l}-0.0322 \\
(0.020)\end{array}$ & $\begin{array}{l}-0.0290 \\
(0.020)\end{array}$ & $\begin{array}{c}-0.0337^{*} \\
(0.020)\end{array}$ & $\begin{array}{c}-0.0342^{*} \\
(0.020)\end{array}$ \\
\hline Terms of trade, $\mathrm{t}-1$ & $\begin{array}{l}-0.0879 \\
(1.218)\end{array}$ & $\begin{array}{c}-0.0942 \\
(1.217)\end{array}$ & $\begin{array}{l}-0.0264 \\
(1.291)\end{array}$ & $\begin{array}{l}0.0804 \\
(1.273)\end{array}$ & $\begin{array}{l}0.2944 \\
(1.244)\end{array}$ & $\begin{array}{l}0.2047 \\
(1.272)\end{array}$ & $\begin{array}{l}0.2899 \\
(1.251)\end{array}$ & $\begin{array}{l}0.2313 \\
(1.262)\end{array}$ \\
\hline Degree of democracy, $\mathrm{t}-1$ & $\begin{array}{c}-0.0422 * * \\
(0.019)\end{array}$ & $\begin{array}{c}-0.0384 * * \\
(0.019)\end{array}$ & $\begin{array}{c}-0.0514 * * \\
(0.021)\end{array}$ & $\begin{array}{c}-0.0513^{* *} \\
(0.021)\end{array}$ & $\begin{array}{c}-0.0495^{* *} \\
(0.021)\end{array}$ & $\begin{array}{c}-0.0513^{* *} \\
(0.021)\end{array}$ & $\begin{array}{c}-0.0519^{* *} \\
(0.021)\end{array}$ & $\begin{array}{c}-0.0496^{* *} \\
(0.021)\end{array}$ \\
\hline Observations & 2,775 & 2,775 & 2,627 & 2,626 & 2,633 & 2,633 & 2,633 & 2,633 \\
\hline Number of countries & 91 & 91 & 80 & 80 & 80 & 80 & 80 & 80 \\
\hline Log likelihood & -570.3 & -575.1 & -520.5 & -521.8 & -525.5 & -525.1 & -524.9 & -526.1 \\
\hline Wald chi2 & 321.4 & 316 & 287 & 280.3 & 279.5 & 274.4 & 282.3 & 269.3 \\
\hline Rho(LR) & 0.471 & 0.475 & 0.479 & 0.484 & 0.479 & 0.494 & 0.486 & 0.502 \\
\hline P-value(Rho) & 0 & 0 & 0 & 0 & 0 & 0 & 0 & 0 \\
\hline AUROC & 0.756 & 0.745 & 0.756 & 0.752 & 0.746 & 0.741 & 0.748 & 0.741 \\
\hline seAUROC & 0.0178 & 0.0177 & 0.0183 & 0.0185 & 0.0185 & 0.0188 & 0.0182 & 0.0185 \\
\hline
\end{tabular}

\section{Duration of Conflict and Political Instability}

We explore whether the duration of conflict and political instability matters. For each variable, we redefine a new variable taking the value of 1 if the conflict or political instability lasts 1 year, or at least 2 years, 3 years, and up to 10 years. We then estimate equation (2) using the Mundlak (1978) estimator. The results are reported in Table 5. We find that conflict and political instability that last only one year has no significant effect on the occurrence of banking crises. However, when the conflict lasts longer, its impact on the occurrence of banking crises become apparent and stronger.

Table 6 shows that the coefficient associated with conflict is positive and significant at the 1 percent level when the conflict lasts at least two years. We can also observe that the coefficient is higher when the conflict lasts 10 years than when it lasts only 2 years. In terms of magnitude of the impact, the probability of experiencing a banking crisis is 25 percent when the conflict lasts 10 years, against 16.4 percent when it lasts two years. This finding can be explained by the fact that when the conflict is becoming prolonged, its adverse impact on the economy and the banking sector intensifies. We find similar results in columns 3, 4, 6 and 8 , suggesting that the probability of a banking crisis increases when political instability persists. The coefficient associated with anti-government demonstrations and general strikes 
become insignificant when they last more than 2 and 3 years, respectively, due to the significant reduction in the number of cases.

\begin{tabular}{|c|c|c|c|c|c|c|c|c|}
\hline \multicolumn{9}{|c|}{ Table 6. Duration of Conflict and Political Instability } \\
\hline VARIABLES & $(1)$ & $(2)$ & $(3)$ & $(4)$ & $(5)$ & $(6)$ & (7) & (8) \\
\hline & $\begin{array}{l}\text { Conflict } \\
\text { (binary) }\end{array}$ & $\begin{array}{l}\text { Conflict } \\
\text { (intensity) }\end{array}$ & $\begin{array}{l}\text { Cabinet } \\
\text { changes }\end{array}$ & $\begin{array}{l}\text { Changes in } \\
\text { Effective } \\
\text { Executive }\end{array}$ & $\begin{array}{l}\text { Anti-Government } \\
\text { Demonstrations }\end{array}$ & $\begin{array}{l}\text { Government } \\
\text { Crises }\end{array}$ & General Strikes & Assassinations \\
\hline \multicolumn{9}{|c|}{ Panel A: Lasting only one year } \\
\hline Variable in column $(\mathrm{X}), \mathrm{t}-1$ & $\begin{array}{l}0.0402 \\
(0.380) \\
\end{array}$ & $\begin{array}{l}-0.0610 \\
(0.349) \\
\end{array}$ & $\begin{array}{l}0.0215 \\
(0.158) \\
\end{array}$ & $\begin{array}{l}0.1698 \\
(0.173) \\
\end{array}$ & $\begin{array}{l}0.0277 \\
(0.087) \\
\end{array}$ & $\begin{array}{l}0.0368 \\
(0.185) \\
\end{array}$ & $\begin{array}{l}0.1251 \\
(0.191) \\
\end{array}$ & $\begin{array}{l}0.0772 \\
(0.273) \\
\end{array}$ \\
\hline \multicolumn{9}{|c|}{ Panel B: Lasting at least two years } \\
\hline Variable in column $(\mathrm{X}), \mathrm{t}-1$ & $\begin{array}{c}1.1330^{* * * *} \\
(0.286)\end{array}$ & $\begin{array}{c}0.4942^{* * * *} \\
(0.172)\end{array}$ & $\begin{array}{c}0.4795^{* * * *} \\
(0.142)\end{array}$ & $\begin{array}{c}0.5990^{* *} \\
(0.238)\end{array}$ & $\begin{array}{c}0.0291^{*} \\
(0.017)\end{array}$ & $\begin{array}{c}0.4784^{* * * *} \\
(0.157)\end{array}$ & $\begin{array}{c}.2162^{* *} \\
(0.099)\end{array}$ & $\begin{array}{c}0.0902 * * \\
(0.042)\end{array}$ \\
\hline \multicolumn{9}{|c|}{ Panel C: Lasting at least three years } \\
\hline Variable in column $(\mathrm{X}), \mathrm{t}-1$ & $\begin{array}{c}1.2874 * * * \\
(0.298) \\
\end{array}$ & $\begin{array}{c}0.5474 * * * \\
(0.174) \\
\end{array}$ & $\begin{array}{l}0.3223^{*} \\
(0.176) \\
\end{array}$ & $\begin{array}{c}0.6230^{*} \\
(0.337) \\
\end{array}$ & $\begin{array}{l}0.0260 \\
(0.018) \\
\end{array}$ & $\begin{array}{c}0.6454^{* *} \\
(0.272) \\
\end{array}$ & $\begin{array}{c}0.2094^{* *} \\
(0.104) \\
\end{array}$ & $\begin{array}{c}0.0934 * * \\
(0.042) \\
\end{array}$ \\
\hline \multicolumn{9}{|c|}{ Panel D: Lasting at least four years } \\
\hline Variable in column $(\mathrm{X}), \mathrm{t}-1$ & $\begin{array}{c}1.1588^{* * * *} \\
(0.302)\end{array}$ & $\begin{array}{c}0.4514^{* *} \\
(0.183)\end{array}$ & $\begin{array}{l}-0.0168 \\
(0.238)\end{array}$ & $\begin{array}{l}0.6500 \\
(0.595)\end{array}$ & $\begin{array}{l}0.0258 \\
(0.019)\end{array}$ & $\begin{array}{c}1.2352^{* * * *} \\
(0.432)\end{array}$ & $\begin{array}{l}0.1421 \\
(0.125)\end{array}$ & $\begin{array}{c}0.1883 * * * \\
(0.060)\end{array}$ \\
\hline \multicolumn{9}{|c|}{ Panel E: Lasting at least five years } \\
\hline Variable in column $(\mathrm{X}), \mathrm{t}-1$ & $\begin{array}{c}1.0238^{* * *} \\
(0.306)\end{array}$ & $\begin{array}{l}0.3308^{*} \\
(0.191)\end{array}$ & $\begin{array}{l}-0.0762 \\
(0.317)\end{array}$ & $\begin{array}{l}1.1809^{*} \\
(0.699)\end{array}$ & $\begin{array}{l}0.0263 \\
(0.020)\end{array}$ & $\begin{array}{c}1.4419^{* * *} \\
(0.470)\end{array}$ & $\begin{array}{l}-0.0577 \\
(0.213)\end{array}$ & $\begin{array}{c}0.4256^{* * * *} \\
(0.106)\end{array}$ \\
\hline \multicolumn{9}{|c|}{ Panel F: Lasting at least six years } \\
\hline Variable in column $(\mathrm{X}), \mathrm{t}-1$ & $\begin{array}{c}1.3082^{* * *} \\
(0.311)\end{array}$ & $\begin{array}{c}0.4562^{* *} \\
(0.191)\end{array}$ & $\begin{array}{l}-0.1093 \\
(0.384)\end{array}$ & $\begin{array}{l}1.3174^{*} \\
(0.743)\end{array}$ & $\begin{array}{l}0.0188 \\
(0.025)\end{array}$ & $\begin{array}{c}1.6203^{* *} \\
(0.782)\end{array}$ & $\begin{array}{l}-0.2888 \\
(0.462)\end{array}$ & $\begin{array}{c}0.5313 * * * \\
(0.156)\end{array}$ \\
\hline \multicolumn{9}{|c|}{ Panel G: Lasting at least seven years } \\
\hline Variable in column $(\mathrm{X}), \mathrm{t}-1$ & $\begin{array}{c}1.4018^{* * * *} \\
(0.324)\end{array}$ & $\begin{array}{c}0.5400^{* * *} \\
(0.197)\end{array}$ & $\begin{array}{l}0.0460 \\
(0.426)\end{array}$ & $\begin{array}{l}1.4833^{*} \\
(0.810)\end{array}$ & $\begin{array}{l}0.0070 \\
(0.035)\end{array}$ & $\begin{array}{l}0.8735 \\
(1.129)\end{array}$ & $\begin{array}{l}0.0235 \\
(0.394)\end{array}$ & $\begin{array}{c}0.6380^{* * * *} \\
(0.202)\end{array}$ \\
\hline \multicolumn{9}{|c|}{ Panel $\mathrm{H}$ : Lasting at least huit years } \\
\hline Variable in column $(\mathrm{X}), \mathrm{t}-1$ & $\begin{array}{c}1.5458^{* * * *} \\
(0.337)\end{array}$ & $\begin{array}{c}0.6565^{* * * *} \\
(0.211)\end{array}$ & $\begin{array}{l}0.3641 \\
(0.397)\end{array}$ & $\begin{array}{l}1.4833^{*} \\
(0.810)\end{array}$ & $\begin{array}{l}-0.0107 \\
(0.051)\end{array}$ & $\begin{array}{l}0.9207 \\
(1.112)\end{array}$ & & $\begin{array}{c}1.5646^{* * * *} \\
(0.572)\end{array}$ \\
\hline \multicolumn{9}{|c|}{ Panel I: Lasting at least nine years } \\
\hline Variable in column $(\mathrm{X}), \mathrm{t}-1$ & $\begin{array}{c}1.6883^{* * * *} \\
(0.350)\end{array}$ & $\begin{array}{c}0.6740^{* * *} \\
(0.214)\end{array}$ & $\begin{array}{c}0.9237^{* *} \\
(0.451)\end{array}$ & $\begin{array}{l}1.4833^{*} \\
(0.810)\end{array}$ & $\begin{array}{l}-0.0490 \\
(0.079)\end{array}$ & & & $\begin{array}{l}1.1000^{*} \\
(0.573)\end{array}$ \\
\hline \multicolumn{9}{|c|}{ Panel J: Lasting at least ten years } \\
\hline Variable in column $(\mathrm{X}), \mathrm{t}-1$ & $\begin{array}{c}1.6462^{* * * *} \\
(0.375)\end{array}$ & $\begin{array}{c}0.6257 * * * \\
(0.223)\end{array}$ & $\begin{array}{c}1.0215^{* *} \\
(0.448)\end{array}$ & $\begin{array}{l}1.4833^{*} \\
(0.810)\end{array}$ & $\begin{array}{l}-0.0764 \\
(0.094)\end{array}$ & & & $\begin{array}{l}0.5283 \\
(0.402)\end{array}$ \\
\hline Control variables & Yes & Yes & Yes & Yes & Yes & Yes & Yes & Yes \\
\hline
\end{tabular}

\section{Transmission Channels}

In this subsection, we explore the channel through which conflict and political instability influence the likelihood of banking crises. As outlined above, we assert that conflict and political instability affect the likelihood of banking crises by creating some fiscal pressures, which in turn transmit to the banking sector. To test this hypothesis, we extract the data on fiscal crises from Gerling et al. (2017). Fiscal crises are defined as episodes of extreme fiscal distress. Our variable fiscal crisis is a binary variable taking the value of 1 if the country is under tight budgetary conditions and 0 otherwise.

We then include an interactive variable between conflict or political instability and fiscal crisis and the latter itself as additional variables. This allows us to test whether the effect of conflict and political instability on banking crises partly or totally transmit through the 
occurrence of fiscal crises. If the coefficients associated with conflict and political instability remain highly significant and their magnitudes do not change, thus conflict and political instability influence the likelihood of banking crises even in the absence of fiscal crises. However, if the coefficients associated with conflict and political instability become insignificant when the interactive term and fiscal crisis are included, then the effect of conflict and political instability on banking crisis can be assumed to operate through a simultaneous occurrence of fiscal crises.

The results are reported in Table 7. They show that the effect of conflict and political instability operates mainly through a simultaneous fiscal crisis. Indeed, the coefficients associated with the different variables of conflict and political instability become insignificant in all columns when the interactive term and fiscal crisis are included, suggesting that the budgetary constraints are key determinants of banking crises, and that some fiscal crises take place simultaneously with the occurrence of conflict and political instability. The coefficient associated with fiscal crisis is positive and significant in all columns. This finding is in line with our main hypothesis.

\begin{tabular}{|c|c|c|c|c|c|c|c|c|}
\hline \multicolumn{9}{|c|}{ Table 7. Transmission Channels } \\
\hline VARIABLES & $(1)$ & $(2)$ & (3) & (4) & $(5)$ & $(6)$ & $(7)$ & $(8)$ \\
\hline & $\begin{array}{l}\text { Conflict } \\
\text { (binary) }\end{array}$ & $\begin{array}{c}\text { Conflict } \\
\text { (intensity) }\end{array}$ & $\begin{array}{l}\text { Cabinet } \\
\text { changes }\end{array}$ & $\begin{array}{l}\text { Changes in } \\
\text { Effective } \\
\text { Executive }\end{array}$ & $\begin{array}{l}\text { Anti-Government } \\
\text { Demonstrations }\end{array}$ & $\begin{array}{l}\text { Government } \\
\text { Crises }\end{array}$ & General Strikes & Assassinations \\
\hline Variable in column $(\mathrm{X}), \mathrm{t}-1$ & $\begin{array}{l}0.5134 \\
(0.340)\end{array}$ & $\begin{array}{l}0.3031 \\
(0.256)\end{array}$ & $\begin{array}{l}0.3006 \\
(0.190)\end{array}$ & $\begin{array}{l}-0.0032 \\
(0.296)\end{array}$ & $\begin{array}{l}-0.0903 \\
(0.086)\end{array}$ & $\begin{array}{l}-0.5423 \\
(0.429)\end{array}$ & $\begin{array}{l}-0.0607 \\
(0.254)\end{array}$ & $\begin{array}{l}0.0495 \\
(0.060)\end{array}$ \\
\hline Fiscal crisis, $\mathrm{t}-1$ & $\begin{array}{c}0.3734 * * \\
(0.190)\end{array}$ & $\begin{array}{c}0.4307^{* *} \\
(0.188)\end{array}$ & $\begin{array}{c}0.4307 * * \\
(0.192)\end{array}$ & $\begin{array}{c}0.4179^{* *} \\
(0.185)\end{array}$ & $\begin{array}{c}0.3953^{* *} \\
(0.185)\end{array}$ & $\begin{array}{c}0.3967 * * \\
(0.183)\end{array}$ & $\begin{array}{c}0.4514^{* *} \\
(0.183)\end{array}$ & $\begin{array}{c}0.4510^{* * *} \\
(0.183)\end{array}$ \\
\hline Variable in column $(\mathrm{X}) *$ fiscal crisis, $\mathrm{t}-1$ & $\begin{array}{c}0.5597^{*} \\
(0.338)\end{array}$ & $\begin{array}{l}0.1554 \\
(0.255)\end{array}$ & $\begin{array}{l}0.0733 \\
(0.212)\end{array}$ & $\begin{array}{l}0.4469 \\
(0.326)\end{array}$ & $\begin{array}{l}0.1528^{*} \\
(0.087)\end{array}$ & $\begin{array}{c}1.1221^{* *} \\
(0.449)\end{array}$ & $\begin{array}{l}0.3469 \\
(0.256)\end{array}$ & $\begin{array}{l}0.0589 \\
(0.080)\end{array}$ \\
\hline Exchange rate, $\mathrm{t}-1$ & $\begin{array}{c}-0.0787 * * \\
(0.038)\end{array}$ & $\begin{array}{c}-0.0783^{* *} \\
(0.038)\end{array}$ & $\begin{array}{c}-0.0815^{* *} \\
(0.039)\end{array}$ & $\begin{array}{c}-0.0827 * * \\
(0.039)\end{array}$ & $\begin{array}{c}-0.0794 * * \\
(0.039)\end{array}$ & $\begin{array}{c}-0.0988^{* * *} \\
(0.041)\end{array}$ & $\begin{array}{c}-0.0890^{* * *} \\
(0.038)\end{array}$ & $\begin{array}{c}-0.0771^{* *} \\
(0.038)\end{array}$ \\
\hline M2/reserves, t-1 & $\begin{array}{c}0.5483^{* * *} \\
(0.125)\end{array}$ & $\begin{array}{c}0.5362 * * * \\
(0.124)\end{array}$ & $\begin{array}{c}0.5416^{* * *} \\
(0.123)\end{array}$ & $\begin{array}{c}0.5502^{* * *} \\
(0.123)\end{array}$ & $\begin{array}{c}0.5565^{* * *} \\
(0.123)\end{array}$ & $\begin{array}{c}0.5679^{* * *} \\
(0.124)\end{array}$ & $\begin{array}{c}0.5493 * * * \\
(0.123)\end{array}$ & $\begin{array}{c}0.5493 * * * \\
(0.123)\end{array}$ \\
\hline Inflation, t-1 & $\begin{array}{c}0.9128^{* * * *} \\
(0.169)\end{array}$ & $\begin{array}{c}0.9217 * * * \\
(0.170)\end{array}$ & $\begin{array}{c}0.9223 * * * \\
(0.167)\end{array}$ & $\begin{array}{c}0.9156^{* * *} \\
(0.169)\end{array}$ & $\begin{array}{c}0.9529^{* * * *} \\
(0.168)\end{array}$ & $\begin{array}{c}0.9344 * * * \\
(0.172)\end{array}$ & $\begin{array}{c}0.9043 * * * \\
(0.171)\end{array}$ & $\begin{array}{c}0.9048 * * * \\
(0.171)\end{array}$ \\
\hline Credit growth, t-1 & $\begin{array}{c}0.5211^{*} \\
(0.295)\end{array}$ & $\begin{array}{l}0.4208 \\
(0.287)\end{array}$ & $\begin{array}{l}0.3800 \\
(0.282)\end{array}$ & $\begin{array}{l}0.3317 \\
(0.281)\end{array}$ & $\begin{array}{l}0.3045 \\
(0.280)\end{array}$ & $\begin{array}{l}0.4215 \\
(0.284)\end{array}$ & $\begin{array}{l}0.3154 \\
(0.281)\end{array}$ & $\begin{array}{l}0.3570 \\
(0.282)\end{array}$ \\
\hline External debt, t-1 & $\begin{array}{c}0.6656^{* * * *} \\
(0.148)\end{array}$ & $\begin{array}{c}0.6769^{* * * *} \\
(0.148)\end{array}$ & $\begin{array}{c}0.7102^{* * *} \\
(0.147)\end{array}$ & $\begin{array}{c}0.7141^{* * *} \\
(0.147)\end{array}$ & $\begin{array}{c}0.7036^{* * *} \\
(0.146)\end{array}$ & $\begin{array}{c}0.6954^{* * *} \\
(0.147)\end{array}$ & $\begin{array}{c}0.6952^{* * *} \\
(0.147)\end{array}$ & $\begin{array}{c}0.7031^{* * * *} \\
(0.147)\end{array}$ \\
\hline GDP per capita, $\mathrm{t}-1$ & $\begin{array}{l}-0.3676 \\
(0.323)\end{array}$ & $\begin{array}{r}-0.3679 \\
(0.322)\end{array}$ & $\begin{array}{c}-0.3278 \\
(0.323)\end{array}$ & $\begin{array}{r}-0.3554 \\
(0.321)\end{array}$ & $\begin{array}{r}-0.3619 \\
(0.326)\end{array}$ & $\begin{array}{r}-0.4238 \\
(0.323)\end{array}$ & $\begin{array}{r}-0.3938 \\
(0.320)\end{array}$ & $\begin{array}{r}-0.3983 \\
(0.322)\end{array}$ \\
\hline Economic growth, $\mathrm{t}-1$ & $\begin{array}{c}-0.0321^{*} \\
(0.019)\end{array}$ & $\begin{array}{c}-0.0321^{*} \\
(0.019)\end{array}$ & $\begin{array}{l}-0.0267 \\
(0.019)\end{array}$ & $\begin{array}{l}-0.0251 \\
(0.019)\end{array}$ & $\begin{array}{c}-0.0298 \\
(0.019)\end{array}$ & $\begin{array}{l}-0.0229 \\
(0.019)\end{array}$ & $\begin{array}{c}-0.0336^{*} \\
(0.019)\end{array}$ & $\begin{array}{c}-0.0355^{*} \\
(0.019)\end{array}$ \\
\hline Terms of trade, $\mathrm{t}-1$ & $\begin{array}{l}-0.0412 \\
(1.204)\end{array}$ & $\begin{array}{l}0.0720 \\
(1.208)\end{array}$ & $\begin{array}{r}-0.1641 \\
(1.219)\end{array}$ & $\begin{array}{l}-0.0686 \\
(1.221)\end{array}$ & $\begin{array}{l}0.0289 \\
(1.218)\end{array}$ & $\begin{array}{l}0.0669 \\
(1.224)\end{array}$ & $\begin{array}{l}0.0202 \\
(1.211)\end{array}$ & $\begin{array}{r}-0.0491 \\
(1.214)\end{array}$ \\
\hline Degree of democracy, $\mathrm{t}-1$ & $\begin{array}{c}-0.0441^{* *} \\
(0.019)\end{array}$ & $\begin{array}{c}-0.0452^{* *} \\
(0.019)\end{array}$ & $\begin{array}{c}-0.0498^{* * * *} \\
(0.019)\end{array}$ & $\begin{array}{c}-0.0515^{* * * *} \\
(0.019)\end{array}$ & $\begin{array}{c}-0.0416^{* * *} \\
(0.019)\end{array}$ & $\begin{array}{c}-0.0520^{* * * *} \\
(0.019)\end{array}$ & $\begin{array}{c}-0.0492^{* * *} \\
(0.019)\end{array}$ & $\begin{array}{c}-0.0465^{* *} \\
(0.019)\end{array}$ \\
\hline Observations & 2,986 & 2,986 & 2,934 & 2,934 & 2,953 & 2,953 & 2,953 & 2,953 \\
\hline Number of countries & 92 & 92 & 92 & 92 & 92 & 92 & 92 & 92 \\
\hline Log likelihood & -592.5 & -597.3 & -594.8 & -594.5 & -595.5 & -592.3 & -595.8 & -598 \\
\hline Wald chi2 & 344.8 & 341.8 & 355.5 & 360.1 & 353.3 & 354.5 & 359.3 & 345.5 \\
\hline Rho(LR) & 0.459 & 0.457 & 0.432 & 0.424 & 0.435 & 0.442 & 0.434 & 0.445 \\
\hline P-value(Rho) & 0 & 0 & 0 & 0 & 0 & 0 & 0 & 0 \\
\hline AUROC & 0.759 & 0.752 & 0.749 & 0.747 & 0.747 & 0.749 & 0.750 & 0.747 \\
\hline SeAUROC & 0.0173 & 0.0172 & 0.0172 & 0.0178 & 0.0177 & 0.0179 & 0.0176 & 0.0175 \\
\hline
\end{tabular}




\section{Robustness CheCKS}

We now estimate a set of different specifications to test the robustness of our results.

\section{A. Use of Alternative Data Sources}

As highlighted in Section 3, several indicators of conflicts and political instability have been used in the literature. In this robustness exercise, we use multiple indicators in an attempt to test the different indicators used so far in the literature to capture the occurrence of conflict and political instability. In Table A2 in the appendix, we use the indicators of country risk from the International Country Risk Guide (ICRG) as in Neumayer (2004). These variables include the risks of internal conflict (civil war, civil disorder and terrorism), external conflict (cross border conflict, interstate war and foreign pressures) and political risk which is an aggregate index combining both internal and external conflict. The results reported in Table A2 are in line with our baseline findings as the coefficients associated with the different indicators are positive and highly significant.

Table A3 presents the results obtained using various indicators of conflict and political instability from multiple sources. In column (1-4) we use some data from the Marshall (2017)'s Major Episodes of Political Violence (MEPV) dataset as in Quereshi (2013) and IMF (2019). In this database, the minimum threshold to be qualified as conflict (500 related deaths) is higher than in our baseline database ( 25 related deaths). We use a binary variable taking a value of 1 if the country experiences a civil war and 0 otherwise in column (1). Marshall (2017) also defines some scores reflecting the intensity of civil war and civil violence based on an eleven-point scale score (0-10), with higher values representing extreme civil war and violence. In column (2), we use the score of civil war, while the score of civil violence is used in column (3). In column (4), we use the aggregate index of total violence, which is the simple average of civil war and civil violence scores. The results show that all four variables are positive and strongly significant at the 1 percent level. Therefore, our baseline findings remain unchanged.

In column (5), our indicator of conflict is from the Correlates of Wars (COW) dataset. In this database, the threshold to be considered as civil war is high as the minimum of conflict-related deaths is 1000 deaths, compared to only 25 in UCDP database used in our baseline specification. The COW database is used in some papers (Bazzi and Blattman, 2014). Table A3 shows that using this data source does not change our findings.

The coefficient associated with conflict is highly significant and higher than that of column (1) in Table 3. With this database, being in conflict raises the probability of a banking crisis from 6.3 percent to 17.7 percent.

In the baseline results in Table 3, we used the number of political assassinations as proxy indicator of political instability. We now use a very similar indicator from Marshall and Marshall (2018) in column (6), which focuses on the assassinations of the ruling executives. This variable takes the value of 1 if the ruling executive is assassinated and 0 otherwise. We still find that the coefficient with our variable of interest is positive and strongly significant, suggesting that the assassinations of the ruling executive is a predictor of banking crises. 
We now look at the cases of terrorism. One data source widely used to capture the occurrence of terrorism attacks is the Global Terrorism Database (Asongu and Nwachukwu, 2017; Lis, 2018). Recent years have been marked by an increase in terrorism attacks in the world, particularly in sub-Saharan Africa (see IMF 2019), leading to severe macroeconomic consequences as infrastructure and human capital are being damaged and businesses delay investment decisions and increase unemployment (Rother et al. 2016). In columns (7) we use a binary variable taking the value of 1 if a terrorist attack occurs in the country and 0 otherwise. The results show that terrorism related attacks are positively associated with higher occurrence of banking crises. The coefficient associated with the variable is strongly significant at the 1 percent level.

As in Neumayer (2004), we use the indicator of political terror from the Political Terror Scale (PTS) database in column (8). This variable captures the violations of basic human rights and includes torture and cruel treatment and punishment, killings and unlawful use of deadly force, political assassinations, kidnappings, forced disappearances, and many other forms of treatments. Given that the source of this database is Amnesty International, the database provides an assessment of political instability made by the humanitarian community, which is very important as they often work closely with the conflict affected populations. The coefficient associated with the variable PTS is positive and significant at the 10 percent level.

Some authors use coups d'état as an indicator of political instability (Fosu, 2002). Several countries have been subject of repetitive military coups, particularly in sub-Saharan Africa (Fosu, 2002; McGowan, 2003). Following these studies, we use the number of coups d'état in column (9). We find that the coefficient associated with this variable is statistically not significant.

Finally, we use the index of state fragility from Marshall and Marshall (2017) and the share of deaths caused by conflict in columns (10) and (11). The state fragility index captures to degree to which a country is vulnerable to political violence. The use of the proportion of the population killed during conflict aims at taking into account the size of countries, in line with IMF (2019). As shown in column (10) and (11), the coefficients associated with these two variables are positive and significant at the 5 percent level, and thus our core finding still holds.

\section{B. Including More Covariates}

To avoid the problem of omitted variables, we include several additional control variables in Table A4. In the first two panels, we check whether controlling for the global conditions will change our results. To this end, we include the S\&P 500 index in panel A and the US 3-years bond yields in panel B. Given the dominance of the US economy and financial sector in the world, there is no doubt that what is happening in the US affect developing countries.

Previous literature on the contagion effects and market transmission from US markets shows that what happens in US markets affect the markets in other countries (Bekaert et al., 2011). The results in panels A and B show that the coefficient associated with conflict and political instability remains broadly positive and strongly significant even if we control for global conditions. 
We control for the role of natural resource endowments in panels C and D. Kinda et al. (2018) and Eberhardt and Presbitero (2018) have found that commodity price fluctuations can lead to banking crises. To capture this potential effect, we include in panel $\mathrm{C}$ the index of commodity prices as in Kinda et al. (2018) and in panel D the total rents from natural resources as percentage of GDP. The results in these two panels are consistent with our baseline findings in Table 3.

In panel E, we include portfolio investment and net inflows, as percentage of GDP, while in panel $\mathrm{F}$ we include the real interest rate. Some studies have found that short-term flows (such as portfolio flows) (Caballero, 2014; Ghosh et al., 2016) are positively associated with the likelihood of a banking crisis. Furthermore, an increase in the real interest rate is a proxy for a tightening of financial conditions which is likely to squeeze banks' balance sheets and increase the probability of a banking crisis (Duttagupta and Cashin, 2011). After controlling for these important covariates, we still find that conflict and political instability increase the likelihood of banking crises, even if the level of significance drops when interest rate is included. This is due to the significant reduction in the number of observations because of the lack of data on real interest rates.

Finally, we include control of corruption, the degree of export diversification and financial development in panels G, H and I, respectively. Previous studies stress the importance of institutions that enforce and secure property rights for financial development and the probability of financial fragility being positively associated with weaker institutions (Demirgüç-Kunt and Detragiache 1998). Barth et al. (2009); and Beck et al. (2006) have shown that when bank supervisors or bank controlling shareholders abuse their power and get involved in corrupted activities, the likelihood of bank failure increases. Regarding export diversification, some studies have found that countries with relatively low export diversification are more susceptible to banking crises (Kinda et al. 2018; Hausmann and Rojas-Suárez, 1996), other studies found that the level of financial development matters (Mathonnat and Minea, 2018). We find that controlling for these variables does not alter our baseline findings.

\section{Alternative Econometric Methods}

In this section, we use the simple probit and logit models, and the profit fixed effects model as robustness checks. As we underlined in Section 4, although the random-effects of Mundlak (1978) is our preferred econometric method, the other methods are also used in some papers either as baseline specification or as robustness check (Caballero, 2016; Ghosh et al., 2016). We estimate equation (2) using these three empirical estimators. The results are reported in Table A5. We find that the coefficients associated with our variable of interest (conflict and political instability) are all positive and significant in all panels. Therefore, our baseline results still hold regardless of the econometric method used.

\section{Concluding Remarks}

Against the background of rising conflict and political instability over the past several decades, the paper investigates whether this phenomenon has led to increased occurrence of banking crises. While there is an extensive literature examining the economic impact of 
conflict and political instability, surprisingly there have been few studies on their impact on the probability of banking crises. This paper has attempted to fill this void.

The paper has provided strong evidence that conflicts and political instability are indeed associated with higher probability of systemic banking crises. Unsurprisingly, it also finds that the duration of a conflict is positively associated with rising probability of a banking crisis. Interestingly, the paper finds that conflicts and political instability in one country can have negative spillover effects in neighboring countries, by raising the probability of banking crises, albeit with lower likelihood.

The paper finds that the primary channel of transmission is the occurrence of fiscal crises following a conflict or political instability. Conflicts and political instability can have a negative impact on the productive capacity of a country and this in turn can reduce government revenue and increase military or other unproductive spending, leading to fiscal crises. More generally, this can generally lead to government dysfunctionality and weakening of institutions.

In terms of policy implications, it is obvious that conflict and political instability have deleterious and far-reaching socio-economic impacts. We concur with Aisen and Veiga (2013) that governments facing conflict and/or political instability need to address their root causes and try to mitigate their negative effects with the appropriate design and implementation of economic policies. Creating adequate fiscal space in normal times can reduce the likelihood of fiscal crises and in turn lower the probability of systemic banking crises. Our results also suggest that policy makers should pay attention to conflicts in neighboring countries even if they themselves are not conflict-afflicted as their banking systems may suffer negative spillovers from their neighbors. 


\section{APPENDICES}

\begin{tabular}{|c|c|c|c|c|c|c|c|c|}
\hline & $\begin{array}{l}\text { Conflict } \\
\text { (binary) }\end{array}$ & $\begin{array}{l}\text { Conflict } \\
\text { (intensity) }\end{array}$ & $\begin{array}{l}\text { Cabinet } \\
\text { changes }\end{array}$ & $\begin{array}{l}\text { Changes in } \\
\text { effective } \\
\text { executive }\end{array}$ & $\begin{array}{l}\text { Anti- } \\
\text { government } \\
\text { demonstrations }\end{array}$ & $\begin{array}{l}\text { Government } \\
\text { crises }\end{array}$ & $\begin{array}{l}\text { General } \\
\text { strikes }\end{array}$ & Assassinations \\
\hline Conflict (binary) & 1 & & & & & & & \\
\hline Conflict (intensity) & $0.9311^{*}$ & 1 & & & & & & \\
\hline Cabinet changes & $0.1139 *$ & $0.1143 *$ & 1 & & & & & \\
\hline Changes in effective executive & $0.0560^{*}$ & $0.0560^{*}$ & $0.4969^{*}$ & 1 & & & & \\
\hline Anti-government demonstrations & $0.1116^{*}$ & $0.1082 *$ & $0.0567^{*}$ & $0.0643^{*}$ & 1 & & & \\
\hline Government crises & $0.1137^{*}$ & $0.1065^{*}$ & $0.2234^{*}$ & $0.2469^{*}$ & $0.1118^{*}$ & 1 & & \\
\hline General strikes & $0.0960 *$ & $0.0843^{*}$ & $0.0617^{*}$ & $0.0818^{*}$ & $0.4531 *$ & $0.1330^{*}$ & 1 & \\
\hline Assassinations & $0.2287 *$ & $0.2390 *$ & $0.0683^{*}$ & $0.0814 *$ & $0.0866^{*}$ & $0.1504 *$ & $0.0800^{*}$ & 1 \\
\hline
\end{tabular}

\begin{tabular}{|c|c|c|c|c|c|c|c|c|c|}
\hline \multicolumn{10}{|c|}{ Table A2. Robustness Checks: Using ICRG Data } \\
\hline \multirow[t]{2}{*}{ VARIABLES } & (1) & (2) & (3) & (4) & $(5)$ & (6) & (7) & $(8)$ & (9) \\
\hline & Civil war & Civil disorder & Terrorism & $\begin{array}{l}\text { Internal } \\
\text { conflict }\end{array}$ & $\begin{array}{c}\text { Cross border } \\
\text { conflict }\end{array}$ & Interstate war & $\begin{array}{l}\text { Foreign } \\
\text { pressures }\end{array}$ & $\begin{array}{l}\text { External } \\
\text { conflict }\end{array}$ & $\begin{array}{l}\text { Aggregate } \\
\text { index }\end{array}$ \\
\hline Variable in column $(\mathrm{X}), \mathrm{t}-1$ & $\begin{array}{c}3.0991 * * * \\
(0.444)\end{array}$ & $\begin{array}{c}4.6497 * * * \\
(0.664)\end{array}$ & $\begin{array}{c}3.2275^{* * *} \\
(0.524)\end{array}$ & $\begin{array}{c}3.6649 * * * \\
(0.530)\end{array}$ & $\begin{array}{c}3.0990 * * * \\
(0.472)\end{array}$ & $\begin{array}{c}2.7336^{* * * *} \\
(0.388)\end{array}$ & $\begin{array}{c}3.3649 * * * \\
(0.513)\end{array}$ & $\begin{array}{c}3.0938^{* * *} \\
(0.451)\end{array}$ & $\begin{array}{c}3.3785^{* * *} \\
(0.486)\end{array}$ \\
\hline Exchange rate, $\mathrm{t}-1$ & $\begin{array}{c}-0.2234 * * * \\
(0.072)\end{array}$ & $\begin{array}{c}-0.2238 * * * \\
(0.073)\end{array}$ & $\begin{array}{c}-0.2074 * * * \\
(0.071)\end{array}$ & $\begin{array}{c}-0.2224 * * * \\
(0.072)\end{array}$ & $\begin{array}{c}-0.2042 * * * \\
(0.069)\end{array}$ & $\begin{array}{c}-0.2233 * * * \\
(0.073)\end{array}$ & $\begin{array}{c}-0.2124 * * * \\
(0.072)\end{array}$ & $\begin{array}{c}-0.2167^{* * *} \\
(0.072)\end{array}$ & $\begin{array}{c}-0.2207 * * * \\
(0.072)\end{array}$ \\
\hline $\mathrm{M} 2 /$ reserves, $\mathrm{t}-1$ & $\begin{array}{c}0.5673 * * * \\
(0.161)\end{array}$ & $\begin{array}{c}0.5663^{* * *} \\
(0.162)\end{array}$ & $\begin{array}{c}0.5826^{* * *} \\
(0.161)\end{array}$ & $\begin{array}{c}0.5743 \text { *** } \\
(0.163)\end{array}$ & $\begin{array}{c}0.5416^{* * *} \\
(0.157)\end{array}$ & $\begin{array}{c}0.5591^{* * *} \\
(0.160)\end{array}$ & $\begin{array}{c}0.5794 * * * \\
(0.161)\end{array}$ & $\begin{array}{c}0.5570^{* * *} \\
(0.160)\end{array}$ & $\begin{array}{c}0.5657 * * * \\
(0.161)\end{array}$ \\
\hline Inflation, t-1 & $\begin{array}{c}0.9080^{* * *} \\
(0.218)\end{array}$ & $\begin{array}{c}0.9188^{* * *} \\
(0.218)\end{array}$ & $\begin{array}{c}0.9192^{* * *} \\
(0.220)\end{array}$ & $\begin{array}{c}0.9085^{* * *} \\
(0.218)\end{array}$ & $\begin{array}{c}0.9090^{* * *} \\
(0.217)\end{array}$ & $\begin{array}{c}0.9305^{* * *} \\
(0.221)\end{array}$ & $\begin{array}{c}0.9355^{* * *} \\
(0.221)\end{array}$ & $\begin{array}{c}0.9262 * * * \\
(0.220)\end{array}$ & $\begin{array}{c}0.9194 * * * \\
(0.220)\end{array}$ \\
\hline Credit growth, t-1 & $\begin{array}{l}0.5585 \\
(0.401)\end{array}$ & $\begin{array}{l}0.5326 \\
(0.399)\end{array}$ & $\begin{array}{c}0.6598^{*} \\
(0.401)\end{array}$ & $\begin{array}{l}0.5623 \\
(0.401)\end{array}$ & $\begin{array}{l}0.5260 \\
(0.400)\end{array}$ & $\begin{array}{l}0.5108 \\
(0.399)\end{array}$ & $\begin{array}{l}0.5542 \\
(0.401)\end{array}$ & $\begin{array}{l}0.5318 \\
(0.400)\end{array}$ & $\begin{array}{l}0.5434 \\
(0.400)\end{array}$ \\
\hline External debt, t-1 & $\begin{array}{c}0.6255^{* * *} \\
(0.198)\end{array}$ & $\begin{array}{c}0.6075^{* * *} \\
(0.197)\end{array}$ & $\begin{array}{c}0.6346^{* * *} \\
(0.197)\end{array}$ & $\begin{array}{c}0.6243^{* * *} \\
(0.198)\end{array}$ & $\begin{array}{c}0.5963^{* * *} \\
(0.196)\end{array}$ & $\begin{array}{c}0.5850^{* * *} \\
(0.198)\end{array}$ & $\begin{array}{c}0.6137 * * * \\
(0.198)\end{array}$ & $\begin{array}{c}0.5942 * * * \\
(0.197)\end{array}$ & $\begin{array}{c}0.6086^{* * *} * \\
(0.198)\end{array}$ \\
\hline GDP per capita, t-1 & $\begin{array}{c}1.8020^{* * *} \\
(0.589)\end{array}$ & $\begin{array}{c}1.8420^{* * *} \\
(0.583)\end{array}$ & $\begin{array}{c}1.2280 * * \\
(0.546)\end{array}$ & $\begin{array}{c}1.7393^{* * *} \\
(0.582)\end{array}$ & $\begin{array}{c}1.4614 * * * \\
(0.563)\end{array}$ & $\begin{array}{c}1.7248^{* * *} \\
(0.579)\end{array}$ & $\begin{array}{c}1.5160 \text { *** } \\
(0.564)\end{array}$ & $\begin{array}{c}1.6287 * * * \\
(0.573)\end{array}$ & $\begin{array}{c}1.7091 * * * \\
(0.579)\end{array}$ \\
\hline Economic growth, t-1 & $\begin{array}{c}-0.0480^{*} \\
(0.026)\end{array}$ & $\begin{array}{c}-0.0488^{*} \\
(0.026)\end{array}$ & $\begin{array}{c}-0.0475^{*} \\
(0.026)\end{array}$ & $\begin{array}{c}-0.0488^{*} \\
(0.026)\end{array}$ & $\begin{array}{c}-0.0493^{*} \\
(0.026)\end{array}$ & $\begin{array}{c}-0.0498^{*} \\
(0.026)\end{array}$ & $\begin{array}{c}-0.0480^{*} \\
(0.026)\end{array}$ & $\begin{array}{c}-0.0492 * \\
(0.026)\end{array}$ & $\begin{array}{c}-0.0488 * \\
(0.026)\end{array}$ \\
\hline Terms of trade, $\mathrm{t}-1$ & $\begin{array}{l}-0.2272 \\
(1.627)\end{array}$ & $\begin{array}{l}-0.2700 \\
(1.641)\end{array}$ & $\begin{array}{l}-0.1309 \\
(1.648)\end{array}$ & $\begin{array}{l}-0.2496 \\
(1.636)\end{array}$ & $\begin{array}{l}-0.2605 \\
(1.629)\end{array}$ & $\begin{array}{l}-0.3036 \\
(1.633)\end{array}$ & $\begin{array}{l}-0.2713 \\
(1.634)\end{array}$ & $\begin{array}{l}-0.2847 \\
(1.633)\end{array}$ & $\begin{array}{l}-0.2834 \\
(1.635)\end{array}$ \\
\hline Degree of democracy, $\mathrm{t}-1$ & $\begin{array}{l}0.0009 \\
(0.027)\end{array}$ & $\begin{array}{l}-0.0017 \\
(0.027)\end{array}$ & $\begin{array}{l}-0.0064 \\
(0.027)\end{array}$ & $\begin{array}{l}-0.0006 \\
(0.027)\end{array}$ & $\begin{array}{l}0.0040 \\
(0.027)\end{array}$ & $\begin{array}{l}0.0020 \\
(0.027)\end{array}$ & $\begin{array}{l}0.0007 \\
(0.027)\end{array}$ & $\begin{array}{l}0.0031 \\
(0.027)\end{array}$ & $\begin{array}{l}0.0019 \\
(0.027)\end{array}$ \\
\hline Observations & 1,847 & 1,847 & 1,847 & 1,847 & 1,847 & 1,847 & 1,847 & 1,847 & 1,847 \\
\hline Number of countries & 71 & 71 & 71 & 71 & 71 & 71 & 71 & 71 & 71 \\
\hline Log likelihood & -362.1 & -361.6 & -371.4 & -363.9 & -367.5 & -363.4 & -367.6 & -365.3 & -364.2 \\
\hline Wald chi2 & 252.4 & 250.5 & 252.6 & 251.8 & 252.4 & 251.4 & 249.3 & 251.6 & 251.9 \\
\hline Rho(LR) & 0.376 & 0.380 & 0.389 & 0.384 & 0.385 & 0.390 & 0.399 & 0.391 & 0.388 \\
\hline P-value(Rho) & 0 & 0 & 0 & 0 & 0 & 0 & 0 & 0 & 0 \\
\hline AUROC & 0.816 & 0.820 & 0.803 & 0.814 & 0.808 & 0.816 & 0.809 & 0.812 & 0.813 \\
\hline seAUROC & 0.0171 & 0.0180 & 0.0190 & 0.0178 & 0.0183 & 0.0178 & 0.0187 & 0.0181 & 0.0179 \\
\hline
\end{tabular}




\begin{tabular}{|c|c|c|c|c|c|c|c|c|c|c|c|}
\hline \multicolumn{12}{|c|}{ Table A3. Robustness Check: Using Data from Different Sources } \\
\hline \multirow[t]{2}{*}{ VARIABLES } & $(1)$ & (2) & (3) & (4) & (5) & (6) & (7) & $(8)$ & (9) & $(10)$ & (11) \\
\hline & $\begin{array}{l}\text { Civil war } \\
\text { (binary)- } \\
\text { Polity IV }\end{array}$ & $\begin{array}{c}\text { Civil war } \\
\text { score-Polity } \\
\text { IV }\end{array}$ & $\begin{array}{l}\text { Civil violence- } \\
\text { Polity IV }\end{array}$ & $\begin{array}{c}\text { Total } \\
\text { violence- } \\
\text { Polity IV }\end{array}$ & COW & $\begin{array}{c}\text { Assassination } \\
\text { of Executive }\end{array}$ & $\begin{array}{l}\text { Terrorism- } \\
\text { GTD }\end{array}$ & PTS & $\begin{array}{l}\text { Number of } \\
\text { Coups d'Etat }\end{array}$ & State fragility & $\begin{array}{l}\text { Conflict deaths } \\
\text { over population }\end{array}$ \\
\hline Variable in column $(\mathrm{X}), \mathrm{t}-1$ & $\begin{array}{c}0.8967 * * * \\
(0.239)\end{array}$ & $\begin{array}{c}1.2454 * * * \\
(0.337)\end{array}$ & $\begin{array}{c}0.2466^{* * *} \\
(0.062)\end{array}$ & $\begin{array}{c}3.2782 * * * \\
(0.820)\end{array}$ & $\begin{array}{c}1.2276 * * * \\
(0.310)\end{array}$ & $\begin{array}{c}1.9710^{* * *} \\
(0.607)\end{array}$ & $\begin{array}{c}0.8284 * * * \\
(0.184)\end{array}$ & $\begin{array}{c}0.1941^{*} \\
(0.103)\end{array}$ & $\begin{array}{c}-0.0674 \\
(0.423)\end{array}$ & $\begin{array}{c}5.3679 * * \\
(2.733)\end{array}$ & $\begin{array}{c}0.3518^{* *} \\
(0.160)\end{array}$ \\
\hline Exchange rate, $\mathrm{t}-1$ & $\begin{array}{c}-0.0846^{* *} \\
(0.038)\end{array}$ & $\begin{array}{c}-0.0892^{* *} \\
(0.039)\end{array}$ & $\begin{array}{c}-0.0853^{* *} \\
(0.039)\end{array}$ & $\begin{array}{c}-0.0860^{* *} \\
(0.039)\end{array}$ & $\begin{array}{c}-0.1848^{* * *} \\
(0.051)\end{array}$ & $\begin{array}{c}-0.0958^{* *} \\
(0.039)\end{array}$ & $\begin{array}{c}-0.0943^{* *} \\
(0.041)\end{array}$ & $\begin{array}{c}-0.0857^{* *} \\
(0.043)\end{array}$ & $\begin{array}{c}-0.0938^{* *} \\
(0.039)\end{array}$ & $\begin{array}{c}-0.5146^{* *} \\
(0.246)\end{array}$ & $\begin{array}{c}-0.0912^{* *} \\
(0.039)\end{array}$ \\
\hline $\mathrm{M} 2 /$ reserves, $\mathrm{t}-1$ & $\begin{array}{c}0.5684 * * * \\
(0.123)\end{array}$ & $\begin{array}{c}0.5555^{* * *} \\
(0.123)\end{array}$ & $\begin{array}{c}0.5603 * * * \\
(0.123)\end{array}$ & $\begin{array}{c}0.5536^{* * *} \\
(0.124)\end{array}$ & $\begin{array}{c}0.5007 * * * \\
(0.141)\end{array}$ & $\begin{array}{c}0.5763^{* * *} \\
(0.124)\end{array}$ & $\begin{array}{c}0.6137^{* * *} \\
(0.128)\end{array}$ & $\begin{array}{c}0.6528^{* * * *} \\
(0.131)\end{array}$ & $\begin{array}{c}0.5646^{* * *} \\
(0.122)\end{array}$ & $\begin{array}{l}0.5459 \\
(0.337)\end{array}$ & $\begin{array}{c}0.5621 * * * \\
(0.124)\end{array}$ \\
\hline Inflation, $\mathrm{t}-1$ & $\begin{array}{c}0.9868^{* * * *} \\
(0.169)\end{array}$ & $\begin{array}{c}1.0115^{* * *} \\
(0.168)\end{array}$ & $\begin{array}{c}1.0015^{* * *} \\
(0.170)\end{array}$ & $\begin{array}{c}1.0062^{* * *} \\
(0.171)\end{array}$ & $\begin{array}{c}0.8236 * * * \\
(0.187)\end{array}$ & $\begin{array}{c}1.0628^{* * *} \\
(0.173)\end{array}$ & $\begin{array}{c}1.0184 * * * \\
(0.173)\end{array}$ & $\begin{array}{c}0.9763^{* * *} \\
(0.179)\end{array}$ & $\begin{array}{c}1.0402^{* * *} \\
(0.170)\end{array}$ & $\begin{array}{c}2.6818^{* * *} \\
(0.910)\end{array}$ & $\begin{array}{c}1.0188^{* * *} \\
(0.172)\end{array}$ \\
\hline Credit growth, $\mathrm{t}-1$ & $\begin{array}{l}0.4463 \\
(0.292)\end{array}$ & $\begin{array}{l}0.4162 \\
(0.294)\end{array}$ & $\begin{array}{l}0.3722 \\
(0.289)\end{array}$ & $\begin{array}{l}0.3741 \\
(0.288)\end{array}$ & $\begin{array}{l}0.3372 \\
(0.317)\end{array}$ & $\begin{array}{l}0.3051 \\
(0.282)\end{array}$ & $\begin{array}{l}0.2782 \\
(0.285)\end{array}$ & $\begin{array}{l}0.3315 \\
(0.299)\end{array}$ & $\begin{array}{l}0.2926 \\
(0.281)\end{array}$ & $\begin{array}{l}0.0636 \\
(0.614)\end{array}$ & $\begin{array}{l}0.3694 \\
(0.285)\end{array}$ \\
\hline External debt, $\mathrm{t}-1$ & $\begin{array}{c}0.8192 * * * \\
(0.146)\end{array}$ & $\begin{array}{c}0.8288 * * * \\
(0.145)\end{array}$ & $\begin{array}{c}0.8222 * * * \\
(0.146)\end{array}$ & $\begin{array}{c}0.8368 * * * \\
(0.146)\end{array}$ & $\begin{array}{c}0.6302 * * * \\
(0.164)\end{array}$ & $\begin{array}{c}0.8286^{* * *} \\
(0.145)\end{array}$ & $\begin{array}{c}0.7155 * * * \\
(0.146)\end{array}$ & $\begin{array}{c}0.5986^{* * *} \\
(0.158)\end{array}$ & $\begin{array}{c}0.8507^{* * *} \\
(0.144)\end{array}$ & $\begin{array}{l}0.6295^{*} \\
(0.342)\end{array}$ & $\begin{array}{c}0.8085^{* * *} \\
(0.144)\end{array}$ \\
\hline GDP per capita, $\mathrm{t}-1$ & $\begin{array}{c}-0.3039 \\
(0.318)\end{array}$ & $\begin{array}{r}-0.1790 \\
(0.323)\end{array}$ & $\begin{array}{c}-0.2186 \\
(0.327)\end{array}$ & $\begin{array}{c}-0.1923 \\
(0.330)\end{array}$ & $\begin{array}{c}2.1684^{* * *} \\
(0.540)\end{array}$ & $\begin{array}{l}-0.4121 \\
(0.320)\end{array}$ & $\begin{array}{c}-0.4042 \\
(0.319)\end{array}$ & $\begin{array}{c}-0.4382 \\
(0.343)\end{array}$ & $\begin{array}{l}-0.3935 \\
(0.316)\end{array}$ & $\begin{array}{r}-1.2565 \\
(0.917)\end{array}$ & $\begin{array}{l}-0.3925 \\
(0.317)\end{array}$ \\
\hline Economic growth, t-1 & $\begin{array}{c}-0.0320^{*} \\
(0.019)\end{array}$ & $\begin{array}{c}-0.0365^{*} \\
(0.019)\end{array}$ & $\begin{array}{c}-0.0271 \\
(0.019)\end{array}$ & $\begin{array}{l}-0.0265 \\
(0.018)\end{array}$ & $\begin{array}{c}-0.0345^{*} \\
(0.019)\end{array}$ & $\begin{array}{c}-0.0251 \\
(0.019)\end{array}$ & $\begin{array}{c}-0.0324^{*} \\
(0.019)\end{array}$ & $\begin{array}{c}-0.0316 \\
(0.020)\end{array}$ & $\begin{array}{c}-0.0350^{*} \\
(0.019)\end{array}$ & $\begin{array}{c}-0.0154 \\
(0.038)\end{array}$ & $\begin{array}{c}-0.0324^{*} \\
(0.019)\end{array}$ \\
\hline Terms of trade, $\mathrm{t}-1$ & $\begin{array}{r}-0.0406 \\
(1.203)\end{array}$ & $\begin{array}{l}0.0700 \\
(1.193)\end{array}$ & $\begin{array}{l}-0.0736 \\
(1.212)\end{array}$ & $\begin{array}{c}-0.1068 \\
(1.210)\end{array}$ & $\begin{array}{l}-0.3437 \\
(1.269)\end{array}$ & $\begin{array}{l}-0.0980 \\
(1.224)\end{array}$ & $\begin{array}{l}0.1038 \\
(1.194)\end{array}$ & $\begin{array}{l}0.0933 \\
(1.209)\end{array}$ & $\begin{array}{l}0.0251 \\
(1.201)\end{array}$ & $\begin{array}{l}-3.5220 \\
(2.742)\end{array}$ & $\begin{array}{l}0.0445 \\
(1.205)\end{array}$ \\
\hline Degree of democracy, $\mathrm{t}-1$ & $\begin{array}{c}-0.0457^{* *} \\
(0.019)\end{array}$ & $\begin{array}{c}-0.0391^{* *} \\
(0.019)\end{array}$ & $\begin{array}{c}-0.0422^{* *} \\
(0.019)\end{array}$ & $\begin{array}{c}-0.0434^{* *} \\
(0.019)\end{array}$ & $\begin{array}{l}-0.0202 \\
(0.022)\end{array}$ & $\begin{array}{c}-0.0468^{* *} \\
(0.019)\end{array}$ & $\begin{array}{c}-0.0541^{* * *} \\
(0.019)\end{array}$ & $\begin{array}{c}-0.0454^{* *} \\
(0.019)\end{array}$ & $\begin{array}{c}-0.0498^{* * *} \\
(0.019)\end{array}$ & $\begin{array}{l}0.0317 \\
(0.048)\end{array}$ & $\begin{array}{c}-0.0470^{* *} \\
(0.019)\end{array}$ \\
\hline Observations & 3,026 & 3,025 & 3,025 & 3,025 & 1,645 & 3,025 & 3,026 & 2,360 & 2,973 & 1,769 & 3,026 \\
\hline Number of countries & 92 & 92 & 92 & 92 & 83 & 92 & 92 & 91 & 92 & 91 & 92 \\
\hline Log likelihood & -598.4 & -596.9 & -597.2 & -597.3 & -443.7 & -601.7 & -594.6 & -537.5 & -603 & -243.2 & -603.3 \\
\hline Wald chi2 & 330.3 & 345.8 & 327.8 & 324.2 & 216.3 & 319.8 & 334.2 & 294.8 & 331.1 & 79.53 & 322.3 \\
\hline Rho(LR) & 0.476 & 0.454 & 0.476 & 0.480 & 0.478 & 0.489 & 0.474 & 0.424 & 0.459 & 0.848 & 0.484 \\
\hline P-value(Rho) & 0 & 0 & 0 & 0 & 0 & 0 & 0 & 0 & 0 & $4.71 \mathrm{e}-09$ & 0 \\
\hline AUROC & 0.751 & 0.756 & 0.752 & 0.751 & 0.749 & 0.736 & 0.753 & 0.733 & 0.740 & 0.756 & 0.741 \\
\hline SEAUROC & 0.0172 & 0.0174 & 0.0170 & 0.0171 & 0.0189 & 0.0183 & 0.0178 & 0.0193 & 0.0179 & 0.0253 & 0.0177 \\
\hline
\end{tabular}




\begin{tabular}{|c|c|c|c|c|c|c|c|c|}
\hline \multicolumn{9}{|c|}{ Table A4. Robustness Check: Including More Covariates } \\
\hline \multirow[t]{2}{*}{ VARIABLES } & $(1)$ & $(2)$ & (3) & $(4)$ & $(5)$ & $(6)$ & $(7)$ & $(8)$ \\
\hline & $\begin{array}{l}\text { Conflict } \\
\text { (binary) }\end{array}$ & $\begin{array}{l}\text { Conflict } \\
\text { (intensity) }\end{array}$ & $\begin{array}{l}\text { Cabinet } \\
\text { changes }\end{array}$ & $\begin{array}{c}\text { Changes in Effective } \\
\text { Executive }\end{array}$ & $\begin{array}{l}\text { Anti-Government } \\
\text { Demonstrations }\end{array}$ & $\begin{array}{l}\text { Government } \\
\text { Crises }\end{array}$ & $\begin{array}{l}\text { General } \\
\text { Strikes }\end{array}$ & Assassinations \\
\hline \multicolumn{9}{|c|}{ Panel A: Adding S\&P 500 index } \\
\hline Variable in column $(\mathrm{X}), \mathrm{t}-1$ & $\begin{array}{c}0.9866^{* * *} \\
(0.244)\end{array}$ & $\begin{array}{c}0.5156^{* * * *} \\
(0.170)\end{array}$ & $\begin{array}{c}0.3466^{* * *} \\
(0.125)\end{array}$ & $\begin{array}{c}0.2928^{* *} \\
(0.147)\end{array}$ & $\begin{array}{c}0.0412^{* * *} \\
(0.016)\end{array}$ & $\begin{array}{c}0.2916^{* *} \\
(0.132)\end{array}$ & $\begin{array}{c}0.1872^{*} \\
(0.101)\end{array}$ & $\begin{array}{c}0.0814^{*} \\
(0.044)\end{array}$ \\
\hline $\mathrm{S} \& \mathrm{P} 500$ index, $\mathrm{t}-1$ & $\begin{array}{c}-0.0015^{* * * *} \\
(0.000)\end{array}$ & $\begin{array}{c}-0.0015^{* * *} \\
(0.000)\end{array}$ & $\begin{array}{c}-0.0014 * * * \\
(0.000) \\
\end{array}$ & $\begin{array}{c}-0.0014^{* * *} \\
(0.000) \\
\end{array}$ & $\begin{array}{c}-0.0015^{* * *} \\
(0.000) \\
\end{array}$ & $\begin{array}{c}-0.0014 * * * \\
(0.000) \\
\end{array}$ & $\begin{array}{c}-0.0014 * * * \\
(0.000) \\
\end{array}$ & $\begin{array}{c}-0.0014 * * * \\
(0.000) \\
\end{array}$ \\
\hline \multicolumn{9}{|c|}{ Panel B: Adding US 3-years bond yield } \\
\hline Variable in column $(\mathrm{X}), \mathrm{t}-1$ & $\begin{array}{c}0.9029 * * * \\
(0.246)\end{array}$ & $\begin{array}{c}0.4127 * * \\
(0.170)\end{array}$ & $\begin{array}{c}0.3713 * * * \\
(0.130)\end{array}$ & $\begin{array}{c}0.3425 * * \\
(0.152)\end{array}$ & $\begin{array}{l}0.0262 \\
(0.018)\end{array}$ & $\begin{array}{c}0.3742^{* * *} \\
(0.133)\end{array}$ & $\begin{array}{c}0.2000^{* *} \\
(0.098)\end{array}$ & $\begin{array}{c}0.0855^{*} \\
(0.045)\end{array}$ \\
\hline US bond yield, $\mathrm{t}-1$ & $\begin{array}{c}0.2251 * * * \\
(0.031) \\
\end{array}$ & $\begin{array}{c}0.2247^{* * *} \\
(0.031) \\
\end{array}$ & $\begin{array}{c}0.2257^{* * *} \\
(0.031)\end{array}$ & $\begin{array}{c}0.2247 * * * \\
(0.031) \\
\end{array}$ & $\begin{array}{c}0.2269 * * * \\
(0.031) \\
\end{array}$ & $\begin{array}{c}0.2358^{* * *} \\
(0.032) \\
\end{array}$ & $\begin{array}{c}0.2261 * * * \\
(0.031) \\
\end{array}$ & $\begin{array}{c}0.2289 * * * \\
(0.031) \\
\end{array}$ \\
\hline \multicolumn{9}{|c|}{ Panel C: Adding commodity price index } \\
\hline Variable in column $(\mathrm{X}), \mathrm{t}-1$ & $\begin{array}{c}1.0015^{* * *} \\
(0.254)\end{array}$ & $\begin{array}{c}0.3948^{* *} \\
(0.175)\end{array}$ & $\begin{array}{c}0.3450^{* * *} \\
(0.130)\end{array}$ & $\begin{array}{c}0.3978^{* * *} \\
(0.154)\end{array}$ & $\begin{array}{c}0.0323 * * \\
(0.016)\end{array}$ & $\begin{array}{c}0.3792 * * \\
(0.149)\end{array}$ & $\begin{array}{c}0.1854^{*} \\
(0.100)\end{array}$ & $\begin{array}{l}0.0637 \\
(0.043)\end{array}$ \\
\hline Commodity prices index, $\mathrm{t}-1$ & $\begin{array}{c}-0.0229 * * * \\
(0.004) \\
\end{array}$ & $\begin{array}{c}-0.0222 * * * \\
(0.004) \\
\end{array}$ & $\begin{array}{c}-0.0213^{* * * *} \\
(0.004)\end{array}$ & $\begin{array}{c}-0.0217^{* * *} \\
(0.004) \\
\end{array}$ & $\begin{array}{c}-0.0223^{* * *} \\
(0.004) \\
\end{array}$ & $\begin{array}{c}-0.0216 * * * \\
(0.004) \\
\end{array}$ & $\begin{array}{c}-0.0220^{* * *} \\
(0.004) \\
\end{array}$ & $\begin{array}{c}-0.0222 * * * \\
(0.004) \\
\end{array}$ \\
\hline \multicolumn{9}{|c|}{ Panel D: Adding natural resource rents $(\% \mathrm{GDP})$} \\
\hline Variable in column $(\mathrm{X}), \mathrm{t}-1$ & $\begin{array}{c}0.9469 * * * \\
(0.246)\end{array}$ & $\begin{array}{c}0.4551^{* * *} \\
(0.167)\end{array}$ & $\begin{array}{c}0.3553 * * * \\
(0.126)\end{array}$ & $\begin{array}{c}0.3416^{* *} \\
(0.149)\end{array}$ & $\begin{array}{l}0.0279 \\
(0.017)\end{array}$ & $\begin{array}{c}0.2775^{* *} \\
(0.134)\end{array}$ & $\begin{array}{c}0.2299^{* *} \\
(0.094)\end{array}$ & $\begin{array}{c}0.0723^{*} \\
(0.043)\end{array}$ \\
\hline Natural resource rents, $\mathrm{t}-1$ & $\begin{array}{c}-0.0356^{*} \\
(0.018) \\
\end{array}$ & $\begin{array}{c}-0.0330^{*} \\
(0.018) \\
\end{array}$ & $\begin{array}{c}-0.0322^{*} \\
(0.018) \\
\end{array}$ & $\begin{array}{c}-0.0337^{*} \\
(0.018) \\
\end{array}$ & $\begin{array}{c}-0.0330^{*} \\
(0.018) \\
\end{array}$ & $\begin{array}{c}-0.0336^{*} \\
(0.018) \\
\end{array}$ & $\begin{array}{c}-0.0316^{*} \\
(0.018) \\
\end{array}$ & $\begin{array}{c}-0.0336^{*} \\
(0.018) \\
\end{array}$ \\
\hline \multicolumn{9}{|c|}{ Panel E: Adding portfolio investment, net flows (\% GDP) } \\
\hline Variable in column $(\mathrm{X}), \mathrm{t}-1$ & $\begin{array}{c}0.7540 * * * \\
(0.258)\end{array}$ & $\begin{array}{c}0.3123^{*} \\
(0.175)\end{array}$ & $\begin{array}{c}0.3804 * * * \\
(0.131)\end{array}$ & $\begin{array}{c}0.3640^{* *} \\
(0.157)\end{array}$ & $\begin{array}{c}0.0307^{*} \\
(0.016)\end{array}$ & $\begin{array}{c}0.4046 * * * \\
(0.144)\end{array}$ & $\begin{array}{c}0.3382^{* * *} \\
(0.100)\end{array}$ & $\begin{array}{l}0.0808^{*} \\
(0.042)\end{array}$ \\
\hline Portfolio invesment, $\mathrm{t}-1$ & $\begin{array}{l}0.0177 \\
(0.023) \\
\end{array}$ & $\begin{array}{l}0.0173 \\
(0.023) \\
\end{array}$ & $\begin{array}{l}0.0180 \\
(0.024) \\
\end{array}$ & $\begin{array}{l}0.0187 \\
(0.024) \\
\end{array}$ & $\begin{array}{l}0.0173 \\
(0.023) \\
\end{array}$ & $\begin{array}{l}0.0146 \\
(0.023) \\
\end{array}$ & $\begin{array}{l}0.0179 \\
(0.023) \\
\end{array}$ & $\begin{array}{l}0.0172 \\
(0.023) \\
\end{array}$ \\
\hline \multicolumn{9}{|c|}{ Panel F: Adding real interest rate } \\
\hline Variable in column $(\mathrm{X}), \mathrm{t}-1$ & $\begin{array}{c}0.7762^{* *} \\
(0.341)\end{array}$ & $\begin{array}{l}0.2566^{*} \\
(0.131)\end{array}$ & $\begin{array}{c}0.4334^{* * *} \\
(0.166)\end{array}$ & $\begin{array}{c}0.4262 * * \\
(0.211)\end{array}$ & $\begin{array}{l}0.0295 \\
(0.020)\end{array}$ & $\begin{array}{c}0.6636^{* * *} \\
(0.184)\end{array}$ & $\begin{array}{l}0.1324 \\
(0.146)\end{array}$ & $\begin{array}{l}0.0587 \\
(0.054)\end{array}$ \\
\hline Real interest rate, $\mathrm{t}-1$ & $\begin{array}{l}0.0056 \\
(0.009) \\
\end{array}$ & $\begin{array}{l}0.0054 \\
(0.009) \\
\end{array}$ & $\begin{array}{l}0.0031 \\
(0.009) \\
\end{array}$ & $\begin{array}{l}0.0048 \\
(0.009) \\
\end{array}$ & $\begin{array}{l}0.0038 \\
(0.009) \\
\end{array}$ & $\begin{array}{l}0.0042 \\
(0.009) \\
\end{array}$ & $\begin{array}{l}0.0029 \\
(0.009) \\
\end{array}$ & $\begin{array}{l}0.0044 \\
(0.009) \\
\end{array}$ \\
\hline \multicolumn{9}{|c|}{ Panel G: Adding control of corruption } \\
\hline Variable in column $(\mathrm{X}), \mathrm{t}-1$ & $\begin{array}{c}0.9095^{* * *} \\
(0.245)\end{array}$ & $\begin{array}{c}0.4487 * * * \\
(0.167)\end{array}$ & $\begin{array}{c}0.3622 * * * \\
(0.126)\end{array}$ & $\begin{array}{c}0.3277^{* *} \\
(0.150)\end{array}$ & $\begin{array}{l}0.0295^{*} \\
(0.017)\end{array}$ & $\begin{array}{c}0.2892 * * \\
(0.134)\end{array}$ & $\begin{array}{c}0.2224^{* *} \\
(0.094)\end{array}$ & $\begin{array}{l}0.0788^{*} \\
(0.042)\end{array}$ \\
\hline Control of corruption, $\mathrm{t}-1$ & $\begin{array}{r}-0.0521 \\
(0.329) \\
\end{array}$ & $\begin{array}{r}-0.0876 \\
(0.329) \\
\end{array}$ & $\begin{array}{r}-0.0365 \\
(0.324) \\
\end{array}$ & $\begin{array}{l}0.0068 \\
(0.319) \\
\end{array}$ & $\begin{array}{r}-0.0997 \\
(0.320) \\
\end{array}$ & $\begin{array}{l}-0.1245 \\
(0.324) \\
\end{array}$ & $\begin{array}{l}-0.1255 \\
(0.315) \\
\end{array}$ & $\begin{array}{l}-0.1102 \\
(0.326) \\
\end{array}$ \\
\hline \multicolumn{9}{|c|}{ Panel H: Adding exports diversification } \\
\hline Variable in column $(\mathrm{X}), \mathrm{t}-1$ & $\begin{array}{c}0.9500^{* * * *} \\
(0.248)\end{array}$ & $\begin{array}{c}0.4488^{* * *} \\
(0.169)\end{array}$ & $\begin{array}{c}0.3499 * * * \\
(0.126)\end{array}$ & $\begin{array}{l}0.2867^{*} \\
(0.153)\end{array}$ & $\begin{array}{c}0.0433^{*} \\
(0.024)\end{array}$ & $\begin{array}{c}0.2890^{* *} \\
(0.137)\end{array}$ & $\begin{array}{c}0.2512 * * \\
(0.099)\end{array}$ & $\begin{array}{c}0.0729^{*} \\
(0.042)\end{array}$ \\
\hline Exports diversification, $\mathrm{t}-1$ & $\begin{array}{c}-0.3619^{* *} \\
(0.147) \\
\end{array}$ & $\begin{array}{c}-0.3471^{* *} \\
(0.147) \\
\end{array}$ & $\begin{array}{c}-0.3754^{* *} \\
(0.149)\end{array}$ & $\begin{array}{c}-0.3715^{* *} \\
(0.149) \\
\end{array}$ & $\begin{array}{c}-0.3403 * * \\
(0.147) \\
\end{array}$ & $\begin{array}{c}-0.3586^{* *} \\
(0.146) \\
\end{array}$ & $\begin{array}{c}-0.3568^{* *} \\
(0.147) \\
\end{array}$ & $\begin{array}{c}-0.3415^{* *} \\
(0.146) \\
\end{array}$ \\
\hline \multicolumn{9}{|c|}{ Panel I: Adding financial development index } \\
\hline Variable in column $(\mathrm{X}), \mathrm{t}-1$ & $\begin{array}{c}0.9353 * * * \\
(0.256)\end{array}$ & $\begin{array}{c}0.3809^{* *} \\
(0.174)\end{array}$ & $\begin{array}{c}0.4075 * * * \\
(0.131)\end{array}$ & $\begin{array}{c}0.3906^{* *} \\
(0.155)\end{array}$ & $\begin{array}{c}0.0411^{*} \\
(0.024)\end{array}$ & $\begin{array}{c}0.4576^{* * * *} \\
(0.152)\end{array}$ & $\begin{array}{c}0.2380^{* *} \\
(0.100)\end{array}$ & $\begin{array}{l}0.0684 \\
(0.042)\end{array}$ \\
\hline Financial development, $\mathrm{t}-1$ & $\begin{array}{l}1.4132 \\
(1.304) \\
\end{array}$ & $\begin{array}{l}1.6558 \\
(1.301) \\
\end{array}$ & $\begin{array}{l}1.4800 \\
(1.295) \\
\end{array}$ & $\begin{array}{l}1.5385 \\
(1.284) \\
\end{array}$ & $\begin{array}{l}1.5286 \\
(1.307) \\
\end{array}$ & $\begin{array}{l}1.5748 \\
(1.303) \\
\end{array}$ & $\begin{array}{l}1.6867 \\
(1.291) \\
\end{array}$ & $\begin{array}{l}1.6488 \\
(1.301) \\
\end{array}$ \\
\hline Control variables & Yes & Yes & Yes & Yes & Yes & Yes & Yes & Yes \\
\hline
\end{tabular}




\begin{tabular}{|c|c|c|c|c|c|c|c|c|}
\hline \multirow[t]{2}{*}{ VARIABLES } & $(1)$ & $(2)$ & (3) & $(4)$ & $(5)$ & $(6)$ & $(7)$ & $(8)$ \\
\hline & $\begin{array}{l}\text { Conflict } \\
\text { (binary) }\end{array}$ & $\begin{array}{c}\text { Conflict } \\
\text { (intensity) }\end{array}$ & $\begin{array}{l}\text { Cabinet } \\
\text { changes }\end{array}$ & $\begin{array}{c}\text { Changes in } \\
\text { Effective Executive }\end{array}$ & $\begin{array}{c}\text { Anti- } \\
\text { Government } \\
\text { Demonstrations }\end{array}$ & $\begin{array}{l}\text { Government } \\
\text { Crises }\end{array}$ & $\begin{array}{l}\text { General } \\
\text { Strikes }\end{array}$ & Assassinations \\
\hline \multicolumn{9}{|c|}{ Panel A: Using probit model } \\
\hline Variable in column $(\mathrm{X}), \mathrm{t}-1$ & $\begin{array}{c}0.3132 * * * \\
(0.086)\end{array}$ & $\begin{array}{c}0.1570 * * * \\
(0.061)\end{array}$ & $\begin{array}{c}0.2163 * * * \\
(0.061)\end{array}$ & $\begin{array}{c}0.2328 * * * \\
(0.079)\end{array}$ & $\begin{array}{l}0.0117^{*} \\
(0.007)\end{array}$ & $\begin{array}{c}0.1593 * * \\
(0.066)\end{array}$ & $\begin{array}{c}0.1246^{* * *} \\
(0.044)\end{array}$ & $\begin{array}{c}0.0538 * * * \\
(0.021)\end{array}$ \\
\hline \multicolumn{9}{|c|}{ Panel B: Using logit model } \\
\hline Variable in column $(\mathrm{X}), \mathrm{t}-1$ & $\begin{array}{l}0.6187 * * * \\
(0.176)\end{array}$ & $\begin{array}{l}0.2864 * * \\
(0.121)\end{array}$ & $\begin{array}{l}0.4357^{* * *} \\
(0.120)\end{array}$ & $\begin{array}{l}0.4817 * * * \\
(0.152)\end{array}$ & $\begin{array}{l}0.0216^{*} \\
(0.011)\end{array}$ & $\begin{array}{l}0.3167 * * * \\
(0.120)\end{array}$ & $\begin{array}{l}0.2200^{* * * *} \\
(0.077)\end{array}$ & $\begin{array}{l}0.0985^{* * *} \\
(0.035)\end{array}$ \\
\hline \multicolumn{9}{|c|}{ Panel C: Using probit fixed effects model } \\
\hline Variable in column $(\mathrm{X}), \mathrm{t}-1$ & $\begin{array}{c}0.5607 * * * \\
(0.153) \\
\end{array}$ & $\begin{array}{c}0.2775^{* * *} \\
(0.106) \\
\end{array}$ & $\begin{array}{c}0.1917 * * \\
(0.078) \\
\end{array}$ & $\begin{array}{c}0.2192 * * \\
(0.095) \\
\end{array}$ & $\begin{array}{l}0.0167 \\
(0.012) \\
\end{array}$ & $\begin{array}{l}0.1243 \\
(0.089) \\
\end{array}$ & $\begin{array}{c}0.1508^{* *} \\
(0.064) \\
\end{array}$ & $\begin{array}{c}0.0610 * * \\
(0.030) \\
\end{array}$ \\
\hline Control variables & Yes & Yes & Yes & Yes & Yes & Yes & Yes & Yes \\
\hline
\end{tabular}




\section{Appendix B1: Definition of Conflict and Political Instability Variables Used in Robustness Checks}

- International Country Risk Guide (ICRG). This database contains two important variables that provides an assessment of the risk of instability: internal conflict and external conflict. The index of internal conflict is an assessment of political violence in the country and its actual or potential impact on governance, and comprises three subcomponents: civil war, terrorism, and civil disorder. The index of external conflict is an assessment both of the risk to the incumbent government from foreign action, ranging from non-violent external pressure to violent external pressure. It encompasses three subcomponents: war, cross-border conflict, and foreign pressures. In the paper, we use not only the indices of internal and external conflicts, but also the different sub-indices. We also compute an aggregate index of conflict, which is the simple average of the internal and external conflict indices.

- Correlates of Wars (COW). In this database, civil war is defined as an armed conflict between an internationally recognized state and (mainly) domestic challengers, able to mount an organized military opposition to the state. A war must have caused more than 1,000 battle-related deaths in total and within at least a three-year period. We define a binary variable taking the value of 1 if the condition is met, and 0 otherwise.

- Political Terror Scale of Amnesty International. This database provides a measure of political terror defined as violations of physical integrity rights carried out by states or their agents. It refers to state-sanctioned killings, torture, disappearances, and political imprisonment. The data are ranged from 1 to 5, with higher values representing widespread and systemic violations of civil and political rights where murders, disappearances, and torture are a common part of life.

- Global Terrorism Database (GTD) by the National Consortium for the Study of Terrorism and Responses to Terrorism (START) (University of Maryland). Terrorism is defined as the threatened or actual use of illegal force and violence by a non-state actor to attain a political, economic, religious or social goal through fear, coercion or intimidation. In order to be considered as a terrorist incident, 3 conditions should be met: (i) the incident must be intentional: the result of a conscious calculation on the part of a perpetrator; (ii) the incident must entail some violence or threat of violence, including violence against property or/and against people; and (iii) the perpetrator of the incident should be sub-national actors. We use the number of terrorism related incidents per year.

- Marshall (2017)'s Major Episodes of Political Violence Database (Center for Systemic Peace). Major episodes of political violence are defined by the systematic and sustained use of lethal violence by organized groups that result in at least 500 directly-related deaths over the course of the episode. We define a binary variable taking the value of 1 if such event occurs and 0 otherwise. The database also contains an eleven-point scale score (0-10) providing an assessment of the intensity of civil war and civil violence. We also use these two scores and an additional aggregate 
score for total violence, which is the simple average of the civil war and civil violence scores.

- Marshall and Marshall (2018)'s Coup d'état Events Database (Center for Systemic Peace). We use two variables from this database capturing whether a military coup occurred in the country and whether the ruling executive was assassinated. A coup d'état is defined as a forceful seizure of executive authority and office by a dissident/opposition faction within the country's ruling or political elites that results in a substantial change in the executive leadership and the policies of the prior regime. We generate a binary variable taking the value of 1 if a coup d'état occurs and 0 otherwise. We also define a binary variable equal to 1 if the ruling executive is assassinated and 0 otherwise.

- Marshall and Marshall (2017)'s State Fragility Index (Center for Systemic Peace). The state fragility index is a composite index based on four dimensions: security, political, economic and social and measures the degree to which a country is vulnerable to political and social violence. The variable ranges between 0 and 25, with higher values meaning extreme fragility. 


\section{References}

Acosta-González, Eduardo, Fernando Fernández-Rodríguez, and Simón Sosvilla-Rivero. 2012. "On Factors Explaining the 2008 Financial Crisis." Economics Letters, 115 (2): $215-217$.

Aisen, Ari, and Francisco José Veiga. 2013. "How Does Political Instability Affect Economic Growth?” European Journal of Political Economy, 29: 151-167.

Alesina, Alberto, and Eliana La Ferrara. 2005. "Ethnic Diversity and Economic Performance." Journal of Economic Literature, 43 (3): 762-800.

Alesina, Alberto, Sule Özler, Nouriel Roubini, and Phillip Swagel. 1996. "Political Instability and Economic Growth.” Journal of Economic Growth, 1 (2): 189-211.

Alesina, Alberto, and Roberto Perotti. 1996. "Income Distribution, Political Instability, and Investment." European Economic Review, 40 (6): 1203-1228.

Angkinand, Apanard P., and Thomas D. Willett. 2011. "Exchange Rate Regimes and Banking Crises: The Channels of Influence Investigated." International Journal of Finance \& Economics, 16 (3): 256-274.

Asongu, Simplice A., and Jacinta C. Nwachukwu. 2017. "The Impact of Terrorism on Governance in African Countries.” World Development, 99: 253-270.

Barro, Robert J., and Rachel McCleary. 2003. "Religion and Economic Growth.” National Bureau of Economic Research.

Barth, James R., Chen Lin, Ping Lin, and Frank M. Song. 2009. “Corruption in Bank Lending to Firms: Cross-Country Micro Evidence on the Beneficial Role of Competition and Information Sharing." Journal of Financial Economics, 91 (3): 361388.

Bazzi, Samuel, and Christopher Blattman. 2014. "Economic Shocks and Conflict: Evidence from Commodity Prices." American Economic Journal: Macroeconomics, 6 (4): 138 .

Banks, Arthur, and Kenneth A. Wilson. 2019. Cross-National Time-Series Data Archive. Databanks International. Jerusalem, Israel

Beck, Thorsten, Asli Demirgüç-Kunt, and Ross Levine. 2006. "Bank Concentration, Competition, and Crises: First Results." Journal of Banking \& Finance 30 (5): 15811603.

Beck, Thorsten, Asli Demirgüç-Kunt, and Ross Levine. 2006. "Bank Supervision and Corruption in Lending." Journal of Monetary Economics, 53:2131-63.

Beckerman, Paul, and Andrés Solimano. 2002. "Crisis and Dollarization in Ecuador: 
Stability, Growth, and Social Equity." World Bank Publications no. 14256, The World Bank.

Beim, David O. 2005. "What Triggers a Systemic Banking Crisis." Working paper, Columbia Business School, New York: https://www8.gsb.columbia.edu/researcharchive/articles/196

Bekaert, Geert, Michael Ehrmann, Marcel Fratzscher, and Arnaud J. Mehl. 2011. "Global Crises and Equity Market Contagion." The Journal of the American Finance Association, 69 (3): 2597-2649.

Bell, Andrew, and Kelvyn Jones. 2015. "Explaining Fixed Effects: Random Effects Modeling of Time-Series Cross-Sectional and Panel Data." Political Science Research and Methods, 3 (1): 133-153.

Büyükkarabacak, Berrak, and Neven T. Valev. 2010. "The Role of Household and Business Credit in Banking Crises.” Journal of Banking \& Finance, 34 (6): 1247-1256.

Caballero, Julián A. 2014. "Do Surges in International Capital Inflows Influence the Likelihood of Banking Crises?” The Economic Journal, 126 (591): 281-316.

Campante, Filipe, and David Yanagizawa-Drott. 2015. "Does Religion Affect Economic Growth and Happiness? Evidence from Ramadan." The Quarterly Journal of Economics, 130 (2): 615-658.

Caprio, Gerard, and Jr and Patrick Honohan. 2008. "Banking Crises.”. The Institute for International Integration Studies Discussion Paper no. 242.

Caprio, Gerard, and Daniela Klingebiel. 1999. Bank Insolvencies: Cross-Country Experience. The World Bank.

Caruana, Jaime, and Stefan Avdjiev. 2012. "Sovereign Creditworthiness and Financial Stability: An International Perspective." Banque de France Financial Stability Review 16 (April): 71-85.

Čihák, Martin. 2007. "Systemic Loss: A Measure of Financial Stability." Czech Journal of Economics and Finance 57 (1-2): 5-26.

Collier, Paul. 1999. "On the Economic Consequences of Civil War." Oxford Economic Papers, 51 (1): 168-183.

Davis, E. Philip, Dilruba Karim, and Iana Liadze. 2011. "Should Multivariate Early Warning Systems for Banking Crises Pool across Regions?" Review of World Economics, 147 (4): 693-716.

Davis, E. Philip, and Mark R. Stone. 2004. "Corporate Financial Structure and Financial Stability." Journal of Financial Stability, 1 (1): 65-91. 
De Bock, Reinout, and Alexander Demyanets. 2012. "Bank Asset Quality in Emerging Markets: Determinants and Spillovers.” IMF Working Paper 12/71. International Monetary Fund.

De Groot, Olaf J. 2010. 'The Spillover Effects of Conflict on Economic Growth in Neighbouring Countries in Africa'. Defence and Peace Economics, 21 (2): 149-164.

Demirgüç-Kunt, Asli, and Enrica Detragiache. 1998. The Determinants of Banking CrisesEvidence from Developing and Developed Countries. IMF Staff Papers, 45 (1):81109.

— 2000. "Monitoring Banking Sector Fragility: A Multivariate Logit Approach." The World Bank Economic Review, 14 (2): 287-307.

—. 2005. "Cross-Country Empirical Studies of Systemic Bank Distress: A Survey." National Institute Economic Review, 192 (1): 68-83.

Depetris Chauvin, Nicolas, and Dominic Rohner. 2009. "The Effects of Conflict on the Structure of the Economy." Verein fur Socialpolitik, Research Committee Development Economics, Proceedings of the German Development Economics Conference, Frankfurt a.M.

Dornbusch, Rudiger, Ilan Goldfajn, Rodrigo O. Valdés, Sebastian Edwards, and Michael Bruno. 1995. "Currency Crises and Collapses." Brookings Papers on Economic Activity, 1995 (2): 219-293.

Duca, Marco Lo, and Tuomas A. Peltonen. 2013. "Assessing Systemic Risks and Predicting Systemic Events.” Journal of Banking \& Finance, 37 (7): 2183-2195.

Duttagupta, Rupa, and Paul Cashin. 2011. "Anatomy of Banking Crises in Developing and Emerging Market Countries.” Journal of International Money and Finance, 30 (2): 354-376.

Eberhardt, Markus, and Andrea Presbitero. 2018. "Commodity Price Movements and Banking Crises.” IMF Working Paper 18/153. International Monetary Fund.

Fernández-Val, Iván, and Martin Weidner. 2016. "Individual and Time Effects in Nonlinear Panel Models with Large N, T.” Journal of Econometrics, 192 (1): 291-312.

Fosu, Augustin Kwasi. 2002. "Political Instability and Economic Growth: Implications of Coup Events in Sub-Saharan Africa." American Journal of Economics and Sociology, 61 (1): 329-348.

Francis, Michael. 2003. “Governance and Financial Fragility: Evidence from a Cross-Section of Countries." Staff Working Paper 2003-34, Bank of Canada.

Gates, Scott, Håvard Hegre; Håvard Mokleiv Nygård, and Håvard Strand. 2012. "Development Consequences of Armed Conflict." World Development, 40 (9): 1713- 
1722.

Gavin, Michael, and Ricardo Hausmann. 1996. "The Roots of Banking Crises: The Macroeconomic Context.” IDB Working Paper No. 262.

Gerling, Kerstin, Paulo A. Medas, Tigran Poghosyan, Juan Farah-Yacoub, and Yizhi Xu. 2017. Fiscal Crises. Journal of International Money and Finance 88: 191-207

Gertler, Mark, and Nobuhiro Kiyotaki. 2010. "Financial Intermediation and Credit Policy in Business Cycle Analysis.” In Handbook of Monetary Economics, 3:547-599.

Elsevier.

Ghobarah, Hazem Adam, Paul Huth, and Bruce Russett. 2003. "Civil Wars Kill and Maim People_Long after the Shooting Stops.” American Political Science Review, 97 (2): 189-202.

Ghosh, Atish R., Jonathan D. Ostry, and Mahvash S. Qureshi. 2016. "When Do Capital Inflow Surges End in Tears?" American Economic Review : Papers \& Proceedings, 106 (5): 581-85."

Gobat, Jeanne, and Kristina Kostial. 2016. "Syria's Conflict Economy.” IMF Working Paper 16/123, Washington DC

Goldstein, Morris, and Philip Turner. 1996. "Banking Crises in Emerging Economies: Origins and Policy Options.” In Trade Currencies and Finance, 301-363.

Gupta, Sanjeev, Benedict Clements, Rina Bhattacharya, and Shamit Chakravarti. 2004. "Fiscal Consequences of Armed Conflict and Terrorism in Low-and Middle-Income Countries." European Journal of Political Economy, 20 (2): 403-421.

Hasanov, Rashad, and Prasad Sankar Bhattacharya. 2019. "Do Political Factors Influence Banking Crisis?" Economic Modelling, 76: 305-318.

Hausmann, Ricardo, and Liliana Rojas-Suarez. 1996. Banking Crises in Latin America. InterAmerican Development Bank.

Hodler, Roland, and Paul A. Raschky. 2014. "Economic Shocks and Civil Conflict at the Regional Level.” Economics Letters, 124 (3): 530-533.

Huang, Chai-Liang. 2019. The Impacts of Political Instability on Banking Development and Operational Efficiencies. National Chung Cheng University

International Monetary Fund. 2019. "Sub-Saharan Africa Regional Economic Outlook: Recovery Amid Elevated Uncertainty.” Accessed July 11, 2019. https://www.imf.org/en/Publications/REO/SSA/Issues/2019/04/01/sreo0419.

Jong-A-Pin, Richard. 2009. "On the Measurement of Political Instability and Its Impact on Economic Growth.” European Journal of Political Economy 25 (1): 15-29. 
Joyce, Joseph P. 2011. "Financial Globalization and Banking Crises in Emerging Markets." Open Economies Review, 22 (5): 875-895.

Kaminsky, Graciela L., and Carmen M. Reinhart. 1999. "The Twin Crises: The Causes of Banking and Balance-of-Payments Problems." American Economic Review, 89 (3): 473-500.

Kaminsky, Graciela, and Carmen Reinhart. 1996. "Banking and Balance of Payments Crises: Models and Evidence." Board of Governors of the Federal Reserve System Discussion Paper No. 544 (Washington: Board of Governor of the Federal Reserve).

Kauko, Karlo. 2014. "How to Foresee Banking Crises? A Survey of the Empirical Literature." Economic Systems, 38 (3): 289-308.

Kinda, Tidiane, Montfort Mlachila, and Rasmané Ouedraogo. 2018. "Do Commodity Price Shocks Weaken the Financial Sector?" The World Economy, 41 (11).

Klomp, Jeroen. 2010. "Causes of Banking Crises Revisited." The North American Journal of Economics and Finance, 21 (1): 72-87.

Kose, M. Ayhan, Eswar Prasad, Kenneth Rogoff, and Shang-Jin Wei. 2009. "Financial Globalization: A Reappraisal." IMF Staff Papers, 56 (1): 8-62.

Laeven, Luc, and Fabian Valencia. 2018. "Systemic Banking Crises Revisited." IMF Working Paper 18/206, Washington DC.

Lai, Brian, and Clayton Thyne. 2007. "The Effect of Civil War on Education, 1980-97." Journal of Peace Research, 44 (3): 277-292.

Lancaster, Tony. 2000. "The Incidental Parameter Problem since 1948." Journal of Econometrics, 95 (2): 391-413.

Lis, Piotr. 2018. "The Impact of Armed Conflict and Terrorism on Foreign Aid: A SectorLevel Analysis." World Development, 110: 283-294.

Mahoney, Paul G. 2001. "The Common Law and Economic Growth: Hayek Might Be Right." The Journal of Legal Studies, 30 (2): 503-525.

Marshall, Monty G. 2017. "Major Episodes of Political Violence (MEPV) and Conflict regions, 1946-2016," Center for Systemic Peace.

Marshall, Monty G. and Donna Ramsey Marshall. 2018. “Coup d'Etat Events, 1946-2017," Center for Systemic Peace.

Marshall, Monty G., and Gabrielle C. Elzinga Marshall. 2017. "Conflict, Governance, and State Fragility. Global Report 2017.” Center for Systemic Peace.

Marshall, Monty G. and Ted Robert Gurr., 2018. "Political Regime Characteristics and 
Transitions, 1800-2017.” Center for Systemic Peace.

Mathonnat, Clement and Alexandru Minea. 2018. "Financial Development and the Occurrence of Banking Crises." Journal of Banking \& Finance, 96: 344-354.

McGowan, Patrick J. 2003. “African Military Coups d'Etat, 1956-2001: Frequency, Trends and Distribution." The Journal of Modern African Studies, 41 (3): 339-370.

Mei, Jianping, and Limin Guo. 2004. "Political Uncertainty, Financial Crisis and Market Volatility.” European Financial Management, 10 (4): 639-657.

Miguel, Edward, Shanker Satyanath, and Ernest Sergenti. 2014. "Economic Shocks and Civil Conflict: An Instrumental Variables Approach." Journal of Political Economy, 112 (4): 725-753.

Mishkin, Frederic S. 2007. "Is Financial Globalization Beneficial?" Journal of Money, Credit and Banking, 39(2/3): 259-294.

—. 2007. The Economics of Money, Banking, and Financial Markets. Pearson Education.

Montalvo, José G., and Marta Reynal-Querol. 2005. "Ethnic Polarization, Potential Conflict, and Civil Wars." American Economic Review, 95 (3): 796-816.

Mueller, Hannes. 2013. “The Economic Costs of Conflict.” Working Paper, International. Growth Centre., London.

Mundlak, Yair. 1978. "On the Pooling of Time Series and Cross Section Data." Econometrica, 46 (1): 69-85.

Murdoch, James C., and Todd Sandler. 2002. "Economic Growth, Civil Wars, and Spatial Spillovers." Journal of Conflict Resolution 46 (1): 91-110.

- 2004. "Civil Wars and Economic Growth: Spatial Dispersion." American Journal of Political Science 48 (1): 138-151.

Neumayer, Eric. 2004. “The Impact of Political Violence on Tourism: Dynamic CrossNational Estimation.” Journal of Conflict Resolution 48 (2): 259-281.

Neyman, Jerzy, and Elizabeth L. Scott. 1948. “Consistent Estimates Based on Partially Consistent Observations." Econometrica, 16 (1): 1-32.

Pasten, Roberto, and James P. Cover. 2010. "The Political Economy of Unsustainable Fiscal Deficits." Cuadernos de Economía, 47 (136):169-189.

Polachek, Solomon W., and Daria Sevastianova. 2012. "Does Conflict Disrupt Growth? Evidence of the Relationship between Political Instability and National Economic Performance." The Journal of International Trade \& Economic Development, 21 (3): 
$361-388$

Popov, Alexander A., and Neeltje Van Horen. 2013. "The Impact of Sovereign Debt Exposure on Bank Lending: Evidence from the European Debt Crisis." DNB Working Paper 382

Qureshi, Mahvash Saeed. 2013. “Trade and Thy Neighbor's War.” Journal of Development Economics, 105: 178-195.

Reinhart, Carmen, Morris Goldstein, and Graciela Kaminsky. 2000. "Assessing Financial Vulnerability, an Early Warning System for Emerging Markets: Introduction.” Munich Personal RePEc Archive.

Rose, Andrew K., and Mark M. Spiegel. 2011. "Cross-Country Causes and Consequences of the Crisis: An Update.” European Economic Review, 55 (3): 309-324.

Rother, Bjoern, Gaelle Pierre, Davide Lombardo, Risto Herrala, Priscilla Toffano, Erik Roos, Allan G. Auclair, and Karina Manasseh. 2016. "The Economic Impact of Conflicts and the Refugee Crisis in the Middle East and North Africa." Staff Discussion Notes 16/8, International Monetary Fund.

Solimano, Andrés. 2003. "Governance Crises and the Andean Region: A Political Economy Analysis.” Macroeconomía del Desarrollo Serie 23. United Nations Publications.

Von Hagen, Jürgen, and Tai-kuang Ho. 2007. "Money Market Pressure and the Determinants of Banking Crises." Journal of Money, Credit and Banking, 39 (5): 1037-1066.

Wooldridge, Jeffrey M. 2010. Econometric Analysis of Cross Section and Panel Data. MIT Press.

World Bank. 2017. The Toll of War: The Economic and Social Consequences of the Conflict in Syria. Washington, DC.: World Bank C. http://hdl.handle.net/10986/27541. 